\title{
Placing the Pillar of Eliseg: Movement, Visibility and Memory in the Early Medieval Landscape
}

\author{
By PATRICIA MURRIETA-FLORES ${ }^{1}$ and HOWARD WILLIAMS ${ }^{2}$
}

\begin{abstract}
Murrieta-Flores, P. and Williams, H. 2017. Placing the Pillar of Eliseg: Movement, Visibility and Memory in the Early Medieval Landscape, Medieval Archaeology 61(1). DOI: $10.1080 / 00766097.2017 .1295926$
\end{abstract}

THE LANDSCAPE CONTEXT of the early gth-century monument known as the Pillar of Eliseg is interrogated here for the first time with GIS-based analysis and innovative spatial methodologies. Our interpretation aims to move beyond regarding the Pillar as a prominent example of early medieval monument reuse and a probable early medieval assembly site. We demonstrate that the location and topographical context of the cross and mound facilitated the monument's significance as an early medieval locus of power, faith and commemoration in a contested frontier zone. The specific choice of location is shown to relate to patterns of movement and visibility that may have facilitated and enhanced the ceremonial and commemorative roles of the monument. By shedding new light on the interpretation of the Pillar of Eliseg as a node of social and religious aggregation and ideological power, our study has theoretical and methodological implications for studying the landscape contexts of early medieval stone monuments.

\section{INTRODUCTION}

Recent research has revealed the profit of combining biographical and landscape approaches to early medieval stone monuments, drawing upon, where available, a range of methods and techniques. ${ }^{3}$ The landscape can be considered far more than a backdrop in which social identities and social memories were inscribed and embodied through the raising and use of carved stones. Instead, locations and spatial settings are instrumental to the intended and acquired social and mnemonic significances of both recumbent and vertically raised free-standing stones. ${ }^{4}$ This paper applies a landscape approach to the study of the Pillar of Eliseg, a unique early medieval stone monument which can be regarded as in situ and linked to public ceremonial and commemorative practice (Fig 1). Our aim is to explore two particular dimensions of this monument's landscape context - movement and visibility - addressing the military, socio-economic context and commemorative significance of the early medieval cross on a mound as a place of assembly in a contested frontier zone.

Comprising fragments of an early medieval stone cross situated on an older mound, the Pillar of Eliseg (Llandysilio yn lâl, Denbighshire, Wales) has a long biography of use and reuse. It is widely accepted as a rare example of an early medieval sculpted stone monument, originally most likely a free-standing cross, that gave its name to the later Cistercian monastery - Valle Crucis - located at, or very close to, its original location. 5 The cross is dated to the early gth century by its long and unique Latin inscription. This was first recorded in the 17th century but now it has been almost completely worn away. ${ }^{6}$ The text honours Cyngen son of Cadell, ruler of the kingdom of Powys, before commemorating his lineage and the deeds and military victories of his great-grandfather Elise ap Gwylog: a 
contemporary of King Offa of Mercia. ${ }^{7}$ The inscription's latter (lower) half, projects back an imagined distant imperial and saintly associations for Cyngen's dynasty by claiming descent from the Roman usurper emperor Magnus Maximus (died 388) and the sub-Roman tyrant Guarthigirn (Vortigern) and citing the blessing of the local saint, Germanus. ${ }^{8}$

Recent fieldwork by Bangor and Chester universities - Project Eliseg (2010-12) has identified new dimensions to the context and biography of the mound upon which the cross was situated, suggesting that text, form and location operated together in the workings of social memory for early medieval audiences. Survey and excavation in the immediate environs of the Pillar using modern archaeological methods, has confirmed the mound was a multi-phased Bronze Age kerbed cairn with multiple burial cists inserted in secondary locations. ${ }^{9}$ The erection and use of the early gth-century cross on this mound can be interpreted as a conscious and overt act of monument reuse, appropriating and transforming a much earlier monument. In doing so, cross and mound became invested with heroic and legendary associations, perhaps tied to those individuals named as ancestors of the kings of Powys in the monument's propagandistic text. ${ }^{10}$ This is an example of early medieval text and context operating in dialogue; the inscription, stone cross and mound working together as a multimedia technology of remembrance. The cross created a link between the present and heroic pasts, thus projecting kingly power and authority, as well as God's blessing, over both people and their territory. In doing so, the 'Pillar' was a commemorative project aimed at cohering past, present and future. ${ }^{11}$ This locality, as with Powys as a whole, was sandwiched between powerful rivals to the west (Gwynedd) and the east (Mercia); the line of succession and independence of Powys subsequently failed with Gwynedd's gth-century expansion. ${ }^{12}$ The Pillar of Eliseg, as an early medieval monument, thus represents a creation of royal patronage that made bold claims by beleaguered rulers in a contested frontier landscape which may have fluctuated between Mercian and Powysian control.

Project Eliseg's fieldwork has also identified new evidence of the Pillar's cultural biography from the Early Middle Ages down to the present, notably its 18th-century antiquarian investigation and subsequent restoration by the local squire, Trevor Lloyd. The cross had remained an enduring medieval landmark adapted into the Cistercian monastic landscape during the 13th century, subsequently toppled by unknown agents in the 17th century, and then mobilised again in the creation of new antiquarian identities for local elites in the late 18th century through the mound's investigation, the Pillar's re-erection and re-inscription. ${ }^{13}$ Inspired by recent biographical approaches to early medieval carved stone monuments ${ }^{14}$ this new evidence, combined with a comprehensive appraisal of the historical, antiquarian and archaeological evidence relating to the monument, provides the basis for a new biography of the monument to be written from prehistory to the present. ${ }^{15}$ Project Eliseg's forthcoming monograph will also consider the monument's reception and reuse in literary and heritage contexts down to the present day, including the impact of the 2010-12 fieldwork upon popular engagements with the monument. ${ }^{16}$

\section{EXPLORING THE PILLAR OF ELISEG'S LANDSCAPE}

By providing new insights into the monument's biography, Project Eliseg has also provided the firm foundation for interrogating the landscape context of the Pillar. Why was the monument situated in this precise location? What do we know about the monument's environs? Was it merely the presence of an ancient mound that motivated its commissioners, but if so, why this mound and not one of the other prehistoric monuments 
that visibly peppered the early medieval landscape? This article shows that many interleaving factors - including possible relationships with other monuments, specifically the region's dykes, the locations of contemporary religious sites and burial sites, settlement patterns and field systems, vegetation, topography and land-use, as well as routes of communication - affected the choice of location for this early medieval monument. ${ }^{17}$

While ancient mounds are recognised as important and widespread features of open-air assembly across northern Europe in various guises, ${ }^{18}$ we can begin to discern a specific logic to the early gth-century reuse of a prehistoric mound as a locus for ceremony and assembly. The Pillar and its mound are situated on a prominent spur, overlooking the landscape as the ground falls away towards the Eglwyseg stream to the east and towards the site of the later Cistercian abbey of Valle Crucis and the Vale of Llangollen to the south (Fig 2). The monument presides over a ridge to its north. To the west, a shallow basin is framed by steeply rising ground. Together, this relatively well-drained area to the north and west might have readily served as an early medieval assembly site, as well as a located on a route of communication between the Vale of Llangollen to the south and the uplands to the north. ${ }^{19}$ In the vicinity of the Pillar, there are tentative but inconclusive traces of high-status early medieval activity in the form of cropmarks and an isolated metal-detector find. ${ }^{20}$ The local situation of the Pillar, as well as the legal character of its Latin text redolent with allusions to legendary pasts, therefore suggests the monument was positioned not only to reuse a prehistoric mound and thus mobilise ancestral and/or spiritual associations, but to dominate and engage with those traversing the valley at a natural arena for aggregation and public ceremony.

The broader environs also need to be considered. The breath-taking wider landscape of the Pillar can be characterised as a narrow and somewhat secluded N-S sidevalley overlooked by higher points and joining the Vale of Llangollen at its southern end. The Pillar is thus located between the hills Fron Fawr and Coed Hyrddyn, west of the impressive towering limestone cliffs of the Eglwyseg Mountain and enclosed from the north-west by the sheer Llantysilio Mountain. The Pillar is also only $1 \mathrm{~km}$ north of the confluence between the Nant Eglwyseg and the Dee. Due to this topographical configuration, the Eglwyseg valley can be considered both a secluded space and a natural passageway between the Clwydian Range and the Dee Valley, crossing through the Llantysilio Mountain via the impressive mountain pass Bwlch yr Oernant (also known as the Horseshoe Pass). Historically, the main road between Llangollen and Ruthin was also through the Eglwyseg valley, taking a turnpike road through Pentre-dwfr, which nowadays also connects to the county of Wrexham and on to Chester. ${ }^{21}$

This is a rural landscape heavily affected by agricultural activity and industry since medieval times, and our knowledge of early medieval and earlier patterns of land-use and settlement patterns are restricted and heavily biased towards the unenclosed uplands. Moreover, there are no monuments in the immediate vicinity of contemporary date to the Pillar of Eliseg: this monument seems striking and distinctive in the context of the Vale of Llangollen, but for the concentration of early medieval carved stones, including a 10th-/11th -century freestanding cross at the putative clas church at Corwen. ${ }^{22}$ However, mapping the archaeological evidence reveals a rich range of prehistoric ceremonial monuments and hilltop fortifications, hinting at a varied landscape of human occupation through the later prehistoric and early historic periods (Fig 3 ). Early medieval people occupied a landscape populated by these inherited fortified sites and mounds, even if it remains unclear how many were reused in the period. ${ }^{23}$ The location was rich in natural affordances which 
attracted and supported the Cistercian monastic community from the $13^{\text {th }}$ century. ${ }^{24}$ The Pillar was not occupying a peripheral or 'liminal' place, but one with access to varied hunting and farming resources, at a clear intersection between geologies and water courses. ${ }^{25}$

This impressive landscape seems to have been of profound significance in terms of elite religious and secular power and practices during later medieval times, as revealed by a triad of significant medieval sites (see Fig 2): Valle Crucis Abbey, Castell Dinas Brân and Llangollen. The foundation of the Cistercian abbey of Valle Crucis by Madog ap Gruffyd in 1201 (only $400 \mathrm{~m}$ south of the Pillar), might have supplanted an earlier church site, although this has left no material trace. ${ }^{26}$ Although these sites, in historical terms, were established four centuries after the erection of the Pillar, the construction of the abbey seems to signal an importance greater than the abundant resources of the area. The abbey's situation might mark the longer-term symbolic prominence and sacred associations of this land.

Meanwhile, the construction of Castell Dinas Brân by the 126 os on the top of the most impressive hill at the valley and on the site of a prehistoric univallate hillfort (only 2 $\mathrm{km}$ south-east from the Pillar), may have appropriated a hilltop utilised for settlement, or as a refuge in the Early Middle Ages, although as with so many potential early medieval fortified sites, there is no surviving diagnostic structural or artefactual evidence of early medieval activity. ${ }^{27}$ Still, the hilltop was strategically located in a riverine location, controlling movement along the Vale of Llangollen, which matches the location of other attested early medieval fortified elite sites. ${ }^{28}$

Thirdly, and no less significantly since both abbey and castle frame the site, there is the nearby clas (mother) church of Llangollen. Although we have no direct evidence regarding how early this site became a Christian cult centre dedicated to St Collen, it was situated at a ford of the River Dee, central to the Vale, and was an important locus of trade and communication in the later Middle Ages. ${ }^{29}$

The discussion thus far provides context for Nancy Edwards' argument that the Pillar was originally situated to mark and form a performative locale of an early medieval assembly site: ${ }^{30}$ a poorly understood category of temporary site that hitherto has lacked a ground-truthed dimension in Wales. ${ }^{31}$ Edwards also speculates, based on the nature of the form of the cross as well as its inscription, ${ }^{32}$ the possibility that the Pillar might have been raised as a focus for royal inauguration ceremonies. Building on this, we suggest in this paper that the cross might have been located between important clas churches, to mark key routes of movement into and through the Nant Eglwyseg into the Vale of Llangollen. ${ }^{33}$

The monument and its landscape were thus intimately connected from its inception. The stone source for the base and pillar might be significant in these regards. The likely source for both stones, while far from certain, is Cefn-y-Fedw Sandstone. This is sourced near the northern edge of the mouth of the Vale, $9 \mathrm{~km}$ east of the Pillar's location upon Ruabon Mountain (and thus just west of Offa's Dyke). ${ }^{34}$ Hence, the transportation and carving of the monument might together have operated as a form of public performance operating at a landscape scale. The final monument would subsequently commemorate this act of extracting and moving the stone up the Dee, and would perpetuate knowledge of its relationships to its source, the route taken, and other locations en route, as well as enhancing its final locale. 35

Together, these arguments help us to consider the influence of this monument's setting in understanding the cross's erection and use in projecting royal power, Christian 
faith and the social memories connecting the two, at a place intended for regular assembly. The martial characteristics of the text, celebrating past military victories, might intimate this was also a locale for mustering troops and/or the actual or imagined location of one or more of the battles of Elise and Concenn. Although our detailed appreciation of the early medieval landscape remains sketchy given the widely recognised difficulty of identifying early medieval settlements and burials in western Britain, this triad of locales in the vicinity suggest that the landscape of the Pillar of Eliseg was positioned not only at a strategic location, but also within a zone of importance for the early medieval societies that inhabited the region. The environs within which the Pillar is placed might even be considered a multi-nodal 'central place' in the Early Middle Ages, where both sacred and secular dimensions coalesced at an assembly place, drawing upon a clear connection to 'ancestral authority'. ${ }^{36}$

However, to date, there has been no systematic attempt to investigate the site in relation to its wider landscape setting. Building on this recent work, and as part of the ERCfunded Past in its Place project investigating topographies of memory from archaeological and literary perspectives, this article explores how the Pillar of Eliseg operated in relation to movement and vision to create and reproduce social memories for those engaging with the monument by inhabiting and traversing the landscape. ${ }^{37}$ Using GIS-based accessibility and visibility analyses, the goals are: to understand the importance of the region in terms of routes of communication and to establish the role of the Vale of Llangollen as a main natural corridor; secondly, to understand the visual structuration of this landscape and identify the possible role of its features in the surveillance of the frontier and of those approaching the Pillar, as well as the visual interaction between lower lands and the surrounding mountains; and finally, through the results of the analyses, to provide interpretations of the role of the Pillar as a presiding feature in this landscape.

Here we demonstrate that the monument not only inhabited a landscape of secular and religious power and perhaps rich myths and legends adhering to the topography and ancient monuments, but also a contested landscape in all its dimensions. In addition to reusing a pre-existing mound, the cross's location was significant because it was bordered by high geographical points, located in a valley enclosed by mountains and what could be considered a natural 'amphitheatre', facilitating visual and other sensory experiences along the main routes of communication to the Pillar. It was also surrounded by exploitable resources, and its only few miles away from the only gateway or 'opening' of the Vale of Llangollen into the Cheshire plain, guarded by Offa's Dyke (traditionally dated to the late 8th century ${ }^{3}$ ) and Wat's Dyke (now plausibly dated to the early gth century: contemporary with the Pillar's construction ${ }^{39}$ ) (Fig 4). Its specific setting and possible spatial relationships with the diverse features in its landscape, add new dimensions to the full story of the Pillar enhancing our contemporary understanding of its early medieval meaning and purpose.

\section{METHODS: ACCESSIBILITY AND VISIBILITY ANALYSES WITH GIS}

While Geographic Information Systems have become a routine dimension in data management for archaeologists, their true potential lies in their capability to carry out advanced spatial analysis. In the case of this research, we carried out two specific types of test. Due to their effectiveness to address questions of geographical but also social character, Viewshed and Cost Surface analyses have been widely used in archaeology, $4^{\circ}$ and were therefore the tests chosen to examine the structuration of the landscape of the 
Pillar of Eliseg. This is because we not only want to explore the visual apprehension and possible impact of the Pillar on those moving through the landscape, but also the contested nature of this landscape. We considered it important to 'escape' from an exclusively dykecentred view of potential routes and lookout points ${ }^{41}$ by considering how this setting was controlled visually in relation to any gatherings taking place at the monument, and in light of its status as a contested landscape at the time of the erection of the cross.

All the analyses were carried out with Arcgis 10.2 with the exception of the total viewshed calculation, where we used the implementation provided by Tabik et al. $4^{2}$ The datasets used in this research include the Historic Environmental Records provided by Clwyd-Powys Archaeological Trust, the Ordnance Survey GIS 'Strategi' layers, and the OS Terrain 5 with $5 \mathrm{~m}$ resolution Digital Elevation Model (DEM) of the region. Full in-depth discussions of the technical details and complexity of Cost Surface and Visibility Analyses, and a full review and assessment of the techniques we have employed in this study, can be consulted elsewhere. 43

\section{COST SURFACE ANALYSES}

Cost Surface Analysis (CSA) can be understood as the mathematical definition of the cost of traversing the landscape. Using a Digital Elevation Model (DEM) and through a calculation inputting particular variables, a cost is assigned to each cell of the map, allowing to determine the expenditure of travelling from one geographical point to another. To create the cost surfacewe used the Schneider and Robbins methodology, ${ }_{1} 44$ which allowed us to establish a relative cost of movement based on the terrain. For this model we regarded rivers as impediments for movement. Although rivers can facilitate the movement of people and commodities, and the Dee can be considered an important artery for medieval riverine transportation from at least Overton down to Chester and out to the Irish Sea, 45 in the case of the study area, none of the rivers are known to have been fully and predictably navigable for all but the smallest of crafts, because of the river's fast flow and many rapids within the Vale. Following recent discussions in relation to Anglo-Saxon England, our focus has been on the importance of overland routes. ${ }^{46}$ In addition, depending on deepness and width, rivers can also constitute significant barriers for those travelling by foot or horseback, emphasised by the importance of the reliable ford (and later bridge) at Llangollen. Therefore, in terms of the model, we considered rivers as obstacles for terrestrial movement in an upland zone, according to the classification given to rivers by the OS as main, minor and secondary, and we took into account places where crossing has been historically recorded such as fords and medieval bridges.

From CSA it is possible to derive Least Cost Paths (LCP). This enables the calculation of natural corridors, or as the name indicates, those pathways that according to the surface calculated will be the least costly, or the easiest to travel on. In this case, we used a sixthdegree polynomial function proposed by Herzog 47 for the calculation of the routes, as its application in other archaeological cases has concluded that this function does not have any of the disadvantages seen in other cost functions..$^{8}$

\section{VISIBILITY ANALYSES}

The aim of visibility analysis is to explore the visual structure or organisation of particular features within the landscape. 49 In the context of archaeological GIS-based theoretical and methodological developments, it has been long acknowledged that visibility is not the only sense that might play an important role in the perception of the 
landscape, and the relevance of other senses has been discussed in depth (see for example Gillings and Wheatley; Frieman and Gillings, ; Llobera; and Wheatley). ${ }^{0}$ Nevertheless, visibility is considered important because in human societies, 'to see' can have significant cognitive, perceptual and social implications that might have a profound effect in settlement patterns, strategies of survival, and apprehension and engagement with settlements and monuments. In addition, in cases of territorial contestation, such as that known to exist here, places that facilitated visual communication and appraisal might have been crucial to control movement and access. However, military, socio-political and economic strategies or advantage are not the only factors in which visibility of the landscape becomes important. To see and to be seen (or to see and not be seen), can be of particular relevance in social and symbolic terms during gatherings and ritualised performances, and this is most certainly pertinent to considering the role of early medieval crosses in their landscape settings. ${ }^{51}$

The Pillar of Eliseg, due to its seemingly strategic position and possible relationship with the fluid frontiers of Mercia and Powys, suggests that visibility from different points in the surrounding landscape, and to and from the location of the monument, might have played a vital role in its commissioners' decision to place the monument in such a setting. Therefore, our analyses test the visual structuration of the landscape where the Pillar sits, as well as its surrounding settings, to establish possible relationships with the frontier, particularly with the two prominent linear earthworks located nearby: Offa's and Wat's dykes.

In the context of GIS, visibility analysis or viewshed can be understood as the mathematical definition of visibility across a landscape using line-of-sight (LOS) algorithms. Taking into account the topography of the terrain through a DEM, the analysis interpolates a straight line between a source point and all other cells within the DEM, identifying the ones that according to their height can be seen from the source point holding intervisibility..$^{22}$ The result of the calculations is a grid of cells that constitute a binary image or map that indicates whether a cell is visible or not, assigning them values of one or zero accordingly.

A variant of this analysis is called Cumulative Viewshed, which allows the exploration of patterns of visibility within a group of sites or places of interest and it consists of the simple union of two or more binary viewsheds. ${ }^{53}$ Binary and Cumulative Viewsheds were carried out, evaluating the visual structuration of the landscape and the Pillar, and in order to incorporate important factors such as the atmospheric refraction and the impact of distance on visibility, we calculated the refractivity coefficient in all analyses.

Another interesting variant of GIS-based visibility is Total Viewshed Analysis. This analysis calculates the visibility of all locations of the terrain in one step. Instead of considering what is visible from the location of one observer, this analysis creates a relative visibility index expressed as the proportion of the area that is visible from each cell. 54 This enables the identification of those locations that have the most and the least visibility, taking into account the totality of the landscape. This was used to evaluate the visual prominence of particular areas of the landscape, and we also created Visibility Index Profiles that show the visibility along Offa's and Wat's dykes, detecting those parts of the earthworks that have maximum and minimum visibility. The possible impact of changes in the vegetation layer in these analyses is fully acknowledged and it has been thoroughly discussed elsewhere. 55 Ideally, GIS-models such as ours should incorporate paleoenvironmental data. However, in this specific case there have not been many studies 
on the early environmental history of the region, and it has been argued that as with other areas of northern Wales, the original woodlands might have been cleared since early prehistoric times, where possibly some small areas of forest were preserved while scrubs, might have been the predominant vegetation in the uplands. ${ }^{6}{ }^{6}$ What is important to bear in mind with GIS based analysis, is that these are models, and as such, the intention here is not to reconstruct or replicate the early medieval landscape, but to test a diversity of hypotheses.

\section{RESULTS}

COST SURFACE ANALYSIS

Carrying out a Cost Surface Analysis of the region (Fig 2), we identified the natural routes of communication that cross and lead in and out of the Vale of Llangollen. In many ways, these confirm to knowledge of the area's historic routes, enshrined crudely by modern roads. However, some important digressions from modern routes have been identified which have a direct bearing on our understanding of the location of the Pillar of Eliseg.

Due to the topographical configuration of the area, there are nine main routes identified through our analyses that allow people to cross the territory with relative ease (Figs 5 and 6). The most anticipated route runs on the northern side of the Dee (almost parallel to it) in an E-W direction along the Vale of Llangollen (Fig 5: Natural Corridor 1). If travelling from east to west upriver, one might expect that this route would follow the River Dee all the way past the entrance of the Nant Eglwyseg and continue upstream towards Corwen. However, it is of great interest to observe that the least cost pathway diverges from the river valley close to Pentrefelin and passes up the Nant Eglwyseg, crosses near the site of Valle Crucis Abbey, and passes only a few metres from the Pillar of Eliseg, before heading west toward Rhwel where it again joins the Dee until it gets eventually to Corwen. Therefore, while the whole of the Nant Eglwyseg from its confluence with the Dee northwards might seem today like a side valley, the Pillar was in fact situated upon the principal W-E corridor through the Vale of Llangollen.

North to the Dee, there are only two main routes of communication leading 'in or out' the Vale of Llangollen and, again, both pass through the Nant Eglwyseg (Fig 5: Natural Corridors 2 and 3). The more easterly route follows the valley northwards and then passes the Pillar. It then follows the foothill of the Eglwyseg Mountain, and heads in the direction of the Aber Sychnant leading to Four Crosses (Fig 5: Natural Corridor 2). Due to the towering cliffs of Eglwyseg Mountain, this is the only route from the territories on the east (aside the one following the Dee) which can reach the 'interior' of the Nant Eglwyseg with some ease. Coming from north-west England, this may have been an alternative route into the Vale of Llangollen.

The other route crossing along the Nant Eglwyseg takes a more northerly direction from the Vale of Llangollen (Fig 5: Natural Corridor 3). It comes from the River Dee following the same path past the Pillar of Eliseg, and then deviates to the north-west close to Pen-y-clawdd Farm, running to the east of the modern Horseshoe Pass. Crossing the Maesrychen Mountain, the route then leads to the Afon Morwynion from which paths diverge in all directions. Following the Morwynion to the south-west, paths lead to Snowdonia and Llyn Tegid (Fig 5: Natural Corridor 4). Heading north-west would take travellers into the Vale of Clwyd. Heading north along the Afon Alun on the eastern side of the Clwydian Range takes the traveller to Halkyn Mountain and the coastal lands of 
Tegeingl. Meanwhile, heading north-east takes one towards Four Crosses and on towards the Dee Estuary and Chester.

Finally, on the southern side of the Dee, another natural corridor parallel to the first one mentioned, follows the river also in an $\mathrm{E}-\mathrm{W}$ direction, following parts of the modern $\mathrm{A}_{5}$ (Fig 5: Natural Corridor 5). This last route is the only one that does not pass immediately by the Pillar of Eliseg, and even here, as we shall discuss below, it passes in the distance and within the viewshed from the monument (Fig 12).

The Pillar of Eliseg can therefore be seen to be a key node in relation to a network of routes heading west, east and north. However, what of routes from the south of the Vale of Llangollen where the Berwyn range restrict movement even further? Coming from the mountains to the south of the Dee, there are four natural corridors that lead into the Vale of Llangollen (Fig 6). One goes over the top of the Berwyn Mountains and bifurcates to the east and west close to Moel Ffema. The route to the west follows the part of the Nant Llechog, passing through Cynwyd Forest and it leads to the intersection of routeways from all directions around Corwen (Fig 6: Natural Corridor 1). Towards the east, it passes around Vivod Mountain (following what is now the North Berwyn Way) before dropping down into Llangollen (Fig 6: Natural Corridor 2). Another natural route follows the eastern foothills of Berwyn through the same route taken by the modern B4500, and it crosses Llanarmon Dyffryn Ceiriog and then Glyn Ceiriog before leading also into Llangollen (Fig 6: Natural Corridor 3). The last natural corridor leading into Llangollen from the southern side of the Dee from Chirk Castle in the east (Fig 6: Natural Corridor 4). The route runs through Cefnuchaf, joining a section of the Llwybr Ceiriog Trail toward Pen-y-coed before finally reaching the Vale at Llangollen. The key point is that Llangollen is the point of convergence for all these routes: only a short distance south-south-east of Eliseg's Pillar.

\section{VISIBILITY ANALYSES}

In terms of the visibility analyses, several observations can be made. An obvious and immediate remark at a larger landscape scale is that the Total Viewshed calculation shows that the Eglwyseg Mountain and some of the summits of the Clwydian and Berwyn ranges are among the most visible features within the landscape (Fig 7). However, another more surprising observation is that despite the relative lower ground around Chirk, the area shows a high value in the relative visibility index. The same can be concluded for all the area east to the late 8th- and early gth-century Mercian dykes (Offa's Dyke and Wat's Dyke). These lower-lying areas show up with medium values in the index due possibly to its open topographical configuration and its position in relation to the mountains from which the region can be seen. This provides an interesting contrast with the areas to the west of the Eglwyseg Mountain, at the interior of both the Vale of Llangollen and the Nant Eglwyseg, which have the lowest values on the index. This indicates that despite being surrounded by high locations, the configuration of the terrain in these areas make the valleys visually disconnected. Therefore, a key feature in terms of viewshed is that the Pillar is located in a very secluded location.

This is also supported by the calculation of the Cumulative Viewshed, where we identified the highest points in the surrounding mountains, and used them to carry out this analysis (Fig 8). The logic of identifying these points was to analyse how feasible it would be possible for watchmen to visually control the natural routes of communication in the surrounding landscape, as well as the access to the Pillar of Eliseg. The results in Figure 8 
show the visible areas from the set of observer points in a graduation from light to darker shades. In darker blue are those areas that can be seen from a larger number of observer points, this is to say, it shows the frequency in which the surface is visible from the set of observers (Fig 8).

From this analysis, two important observations can be made. Firstly, deriving a graphic (Fig 9) from the cumulative viewshed which shows the locations ( $x$-axis) that are 'seen' by a higher number of observers ( $y$-axis), reveals those points that are highly visible in the network. In this case, Moel y Gamelin, Moel Morfydd, Vivod Mountain, and the former Cefn Ucha Common (identified by their Location IDs in Fig 9 as points 1, 7, 11 and 24 ) have the highest values, indicating that they can be seen from most of the observer points set. This makes them optimal locations to be chosen as possible 'look-out' positions in order to maintain surveillance of the landscape. In addition, the view from these locations covers a vast extension of the interior and exterior of the Eglwyseg and Llangollen valleys, reaching not only the highest points in the Clwydian Range, Llantysilio and the Eglwyseg mountains, but also the main routes of communication leading into the Vale of Llangollen from the east and south (Fig 10). These locations, and particularly Cefn Ucha Common (location 24), might have played an important role in relation to the visual control of the region (discussed below). Secondly, the very low values evident in the areas where the natural corridors are, in both the Eglwyseg and Llangollen valleys, reveals that the cumulative viewshed analysis supports the observation made in the Total Viewshed about visual isolation, indicating that the main routes of communication were visually covered by a small number of locations situated at the highest points of this landscape (Fig 10).

The viewshed from the Pillar of Eliseg reveals that visibility is very restricted and it has a main NW-SE direction (Fig 11). In terms of visual dominance, it covers some sections of the main route that crosses the Nant Eglwyseg. It is also interesting to observe that the viewshed from the Pillar of Eliseg reaches Cefn Ucha Common (location 24) to its southeast, which as explained previously, is one of the highest and most visible points in this landscape of the Vale and its immediate environs. Further calculation of Lines of Sight reveal that Cefn Ucha Common is not only intervisible with the Pillar of Eliseg and Dinas Brân, but also with the highest points along the Mercian frontiers, including those that would have been crucial for the surveillance of both Offa's and Wat's dykes. In the opposite direction, a small area at the top of the ridge-line beside Bwlch yr Oernant (Horseshoe Pass) is intervisible with the Pillar, meaning that a lookout post and/or beacon set here could warn those gathered at the Pillar of anyone approaching into the Nant Eglwyseg. Incidentally views northwards from this area stretch as far as Moel Famau: the highest point of the Clwydian Range. The implication derived from this, is that through achieving an oversight of these locations, an intervisible network of lookout points emerges. These sites may also have hosted beacons, controlling the area in terms of the surveillance of the frontier, and the principal routes of access into British territory through the interior of the Vale of Llangollen and the Nant Eglwyseg, and the Clwydian Range.

Bwlch yr Oernant to the north, and Cefn Ucha Common to the south, were key in this regard. For the latter, just a short distance to the west of point 24 on Cefn Ucha Common, a short dyke, Clawdd Collen, was identified as a possible early medieval earthwork. ${ }^{57}$ The location of this undated dyke could be related to this postulated strategic position, maybe monitoring or protecting this area as an important point of visual access and control to the Vale. 
Another point of relevance in terms of visibility is the location of Castell Dinas Brân (Fig 12). This striking hill commands a visually dominant position over the area around the historic church of Llangollen and almost all the routes along the Dee from Offa's Dyke and Wat's Dyke to the east, to Berwyn Mountain to the south-west: areas postulated as territories of Powys during the 8th and gth centuries. In addition, all the locations that have direct visual access to the Pillar also have visual access to Castell Dinas Brân. As with the Pillar, this steep hill also holds a direct visual connection with Cefn Ucha Common. Therefore, while Castell Dinas Brân is not intervisible with the Pillar of Eliseg, one cannot approach the Pillar from the east or south without being observed from Castell Dinas Brân, or from the north and the south without being observed from Cefn Ucha Common.

Analysing the visibility from the Llantysilio Mountain and Cyrn-y-Brain, it can be observed that the highest points on these mountains do not have direct visual access to the Pillar (Fig 13). Nevertheless, they hold intervisibility with the great majority of other higher locations, including Dinas Brân and the prehistoric hillforts located in the Clwydian range. In addition, the natural corridors north of the Llantysilio Mountain and the one leading to the Clwydian Valley can be also entirely dominated from many of these locations.

In assessing visibility toward the dykes, the analysis revealed that while several transects of Offa's Dyke can be observed from a small number of key points in the surrounding mountains, Wat's Dyke can be seen from even fewer locations since it is located further east, away from the higher ground. From a total length of $20.591 \mathrm{~km}$, $63.81 \%(13.140 \mathrm{~km})$ of line of Offa's Dyke is visible from the different peaks at Eglwyseg Mountain and the hills south to the Vale of Llangollen. The transect of the dyke just in front of the Eglwyseg Mountain presents itself as particularly high in terms of visibility. Only a few lookout points would have been needed to visually dominate almost its entire length $(17,22,24$ and 25) (Fig 14).

The case of Wat's Dyke is even clearer. This $62 \mathrm{~km}$ long linear earthwork stretching from Basingwerk on the Dee estuary south to Maesbury in Shropshire is rarely if ever discussed in relation to the Pillar of Eliseg, with emphasis usually places instead on connections with Offa's Dyke..$^{8}$ Yet, thanks to the excavations at Gobowen, it is now demonstrable that the dyke might be broadly contemporary to the raising of the Pillar of Eliseg, at a time when Offa's Dyke was long established and perhaps already abandoned. It is likely to have been constructed by one of Offa's longer-lasting Mercian royal successors, perhaps Coenwulf, Wiglaf or Beorhtwulf, to combat either the threat posed by Powys and/or the rising power of their western rivals in Gwynedd. ${ }^{59}$ Equally significant, Wat's Dyke, not Offa's Dyke, had a more enduring significance as a frontier up to Domesday, as revealed by the distribution of hidated (east of its course) versus unhidated (west of the dyke) manors and the distribution of English and Welsh place-names. ${ }^{60}$ An outstanding $92.18 \%(16.550 \mathrm{~km})$ of the length postulated for this dyke $(17.952 \mathrm{~km})$ is visible from the calculated points. In fact, in this case, only two observer points (22 and 26 ) would be needed to observe the full $92.18 \%$ of the dyke, and therefore, to visually control the movement of people and their animals along the principal routes to the east of the Eglwyseg Mountain (Fig 15).

A very interesting contrast is apparent when the views from the highest points in the mountains close to the frontier are compared with the actual visibility from the dykes themselves. One might expect that visibility from the highest points along the Eglwyseg Mountain would not only cover a wider area of the landscape, but also visually dominate far more of the natural corridors. Nevertheless, although the visibility from the highest points 
along the frontier (eg Eglwyseg Mountain), covers a larger area including the top of Berwyn, Llantysilio and Clwydian range, the visibility calculated from Offa's Dyke covers areas that these points do not reach, including the east foothills of Eglwyseg Mountain and a large portion of the entrance into the Llangollen Valley (Fig 16). Moreover, from Offa's Dyke, it is possible to see some of the summits in Berwyn, Llantysilio, Hope Mountain and even small parts of the Clwydian Range. The visibility from the far end of Offa's Dyke near Treuddyn, would have covered almost all of Wrexham, the Dee Basin up to Chester and parts of Buckley. In the case of Wat's Dyke, the visibility from the monument is also outstanding, covering the entrance into the Vale of Llangollen and some of the summits of its hills south to the Dee (Fig 17). Furthermore, the view from Offa's Dyke covers a larger length $(130.321 \mathrm{~km})$ of the natural corridors than expected, and it is almost the same length covered by the viewshed from the highest locations at Eglwyseg Mountain (146.948 km). In the case of the view from Wat's Dyke, the length of corridors covered $(93.52 \mathrm{~km})$ does not fall far from these measurements. This prompts questions over assumptions regarding the functions and roles of the dykes and their relationship to each other. ${ }^{61}$ For the purpose of the discussion here, however, the point to be made is that those wishing to control access to the Pillar of Eliseg in terms of both contest and collaboration with populations close to, and east of the dykes, could do so relatively easily. In short, the Pillar of Eliseg was a secluded location, but it was central to routes and readily protected and controlled in terms of postulated lookout points.

\section{DISCUSSION}

Due to the topographical configuration of this terrain, the Vale of Llangollen can be identified as the most direct route of communication in an E-W axis from the Cheshire Plain to the Welsh uplands, but also it constituted a socio-political and religious hub. This natural corridor, leads to a crossroads after Corwen, where three other main routes can be taken further west, north, or to the south-west of Wales. In this sense, the Vale was not only of crucial importance for local communications in north-east Wales and north-west England in the early medieval period, but for long-distance overland routes, just as it was in later centuries. ${ }^{62}$ This connectivity makes the Vale of Llangollen not only an important route of communication, but also a crucial corridor in terms of military, commercial and political strategy for the region and beyond. Although there are other W-E routes through northeast Wales including the Flintshire coast, the Vale has advantages over these in terms of the range of possible destinations that can be reached both to the east and the west, and also because it is easier to traverse this terrain unobserved.

Therefore, to control the bottleneck created by the Vale of Llangollen either side of the Pillar of Eliseg meant to dominate the most direct and well-connected route inland through north-east Wales. In this sense, the military and socio-political control or management of this land route and corridor would have allowed the access to the main and central corridors of communication within Wales, and therefore, the possibility to control any commercial or military enterprise both 'from' or 'into' this territory but also through it. Indeed, as Reynolds and Langlands point out, it is not merely places of topographical shift and viewshed thresholds where crosses might mark horizons as landmarks, but also principal crossroads, that seem to acquire crosses in early medieval Britain. ${ }^{63}$ In addition, the significance of the Pillar in terms of its setting and inscription is such, that it would have been a powerful representation of claims to authority over this locale, capable of presiding over a range of assemblies and other gatherings, including religious festivals and markets, 
involving groups traversing into the Vale of Llangollen from all directions. In this sense, the results from the analyses can be interpreted in terms of the different affordances this landscape enables.

\section{A PLACE FOR TERRITORIAL DEFENCE}

The Pillar's relationship to regional and supra-regional overland and riverine communication routes at a crossroads is one important dimension revealed by this analysis; another is the local topographical situation. Nant Eglwyseg has been shown to play significant role, due to its topographical configuration. The valley can be thought of as an 'antechamber' west of the Mercian frontier. It was both located on the main W-E axis of movement west of the dykes but also constituted the main natural corridor along a N-S axis offering the only alternatives 'in or out' the Vale of Llangollen from the north bank of the Dee. The Eglwyseg valley therefore, seems to have been an important passageway in its own right, with the Pillar occupying a central place, but it also occupied a strategic position in relation to fluid and contested frontiers with Mercia to the east, and with Gwynedd and Tegeingl to the west and north respectively. As the Least Cost Path Analysis indicates, despite being surrounded by high mountains, the Pillar and its immediate environs in the Vale of Llangollen constituted a well-connected location.

There are three types of quality to the location that demand further attention. First, this location has a vast expanse of accessible land and important natural resources. The richness of the area is testified to by the abundant summer pastures, fertile land for agriculture, mining resources, woods for hunting and gathering, and plentiful fishing, as well as sacred places (ancestral burial mounds and at least one known holy well), and water sources. ${ }^{64}$ Secondly, the Pillar is located in what could be considered a secluded location, but also a place that constituted a gateway to the frontier. Thirdly, by controlling the right locations in this region, as demonstrated by the visibility analysis, it would have been possible to command a network of lookout points and beacons akin to those reconstructed by a combination of place names and archaeology for southern England. ${ }^{65}$ Indeed such a system is often postulated as a defensive system for the Mercian dykes ${ }^{66}$, in the environs of the Pillar. This surveillance system at the frontier would also have afforded careful control over movement to and from the Pillar. Finally, the monument's proximity to main routes of communication within the area, and its hidden character, makes it both secure and accessible.

As such, it was ideal not only for mustering forces but also as a place superlative for territorial defence, very difficult to approach unseen and thus providing a base for mobile forces or the withdrawal of non-combatants. In this sense, and in terms of military strategy, it would have been possible to establish a large camp in this place, which has several advantages in comparison with the surrounding landscape. For the same reasons, it would have been able to sustain seasonal assemblies exploiting the natural resources available, including perhaps deer, boar and fish. ${ }^{67}$ The cross at such a location not only marked and served as a performative and mnemonic locus for such gatherings, but would have perhaps demarcated this as a sanctuary where groups might meet unhindered.

Surveillance of the frontier was obviously not only the concern of those on the British side of the dykes, but we emphasise this to avoid taking a purely Mercian perspective. ${ }^{68}$ The general consensus of modern research regarding Offa's and Wat's dykes is that their primary function was to control movement and provide protection against raiding along the frontier, but also to be 'performative' and visually impress those 
approaching from the west, as well as to surveil land to their west. ${ }^{69}$ Indeed, they might have been especially monumental, both in terms of their build and incorporation of prominent natural features, to 'oppose' locales of British power, including the Vale of Llangollen. ${ }^{70}$ The topographic effect of Offa's Dyke, is demonstrated on our LCP analysis, which results show how routes of communication are affected by it. Natural corridors coming from the Welsh mountains, and leading to the dyke, tend to follow its contour. The dyke may have also channelled communications toward possibly regulated gaps, as suggested by some of the corridors, which cross the dyke in historically interesting places such as Chirk Castle and Pen-y-Gardden fort (close to Ruabon). ${ }^{71}$ In fact, adding Wat's Dyke to the equation, shows that routes of communications tend to funnel between the dykes. This demonstrates what others have speculated, that indeed, the dykes probably had the function of controlling movement both across and along the frontier they constituted, defended and surveilled. ${ }^{72}$

It has been argued that these linear earthworks served primarily to dissuade or at least impede movement across the border 73 . This idea has been derived from the fact that archaeological investigations have failed so far to identify watchtowers or strongholds along the dykes. ${ }^{74}$ Nevertheless, Ray and Bapty reassert arguments for the careful and strategic positioning of the dykes, as well as variations in their build, in relation to visibility. From the analyses, it can be concluded that the visibility from the dykes takes in a larger area than expected: from the dykes, it was not only possible to visually control at least part of the entrance to the Vale of Llangollen and the entire foothills of the Eglwyseg and Ruabon Mountains and as a consequence dominate access to and from Welsh territory, but also visual control was possible of vast sections of the routes of communication to the east, as well as some parts of the routes around Vivod Mountain. From a British perspective, the visibility analysis indicates that the visual control of the dykes (from the west) was feasible from the Eglwyseg Mountain, it also shows that the visual surveillance of the frontier might have worked both ways. Therefore, our analysis demonstrates that watchtowers were in fact unnecessary from a Mercian perspective, as visibility from the dykes themselves is expansive, even from the heights recorded from the surviving monuments today. Although there has been controversy over whether the frontier was uniformly established and sustained, and if so how guarding it might have operated, ${ }^{75} \mathrm{Noble}^{76}$ made the case for the possible presence of 'patrols' in the frontier. In this manner, although the Mercian dykes might have had among others, the function of channelling movement and to protect from some forms of raiding, they might have also played an important role in terms of visual surveillance. Considering that the Welsh side benefitted from mountains as an effective defence and surveillance resource, it is possible that the dykes were built, at least in part, as a counter measure or compensation to facilitate the visual control of the frontier.

\section{A PLACE OF SYMBOLIC AND POLITICAL DEFINITION}

The importance of the natural corridor of the Eglwyseg valley is further emphasised by its ancestral landscape. The location of the Pillar of Eliseg constitutes a point of interest from geographical and cultural perspectives. It is of great interest to observe that the least cost paths crossing the valley, pass only few metres away from the Pillar of Eliseg. However, we need to remember that the Pillar was erected on top of a Bronze Age funerary monument. 77 This would have had practical, but also social implications. The relationship between the monument and the pathways, can be seen as an earlier association between the Bronze Age monument and the natural routes of communication through the valley, 
and emphasises the importance of this corridor from late prehistory. Moreover, due to the unique location of the monument as a central node in the main corridors of the Eglwyseg Valley, the mound could be also understood as a possible landscape marker at the crossroad where corridors leading in or out the Valle of Llangollen to the west, the northwest and the north-east divided (Fig 5 ). This means that any observation we could make regarding the properties at a landscape scale of the Pillar of Eliseg, are conditioned by its relationship with the Bronze Age kerbed cairn. In this sense, it is certain that the people that erected the cross on the mound realised the spatial connexions of the mound and its broader landscape. In fact, it seems likely that they exploited this connection. As noticed by Edwards, ${ }^{78}$ the use of the verb recitare on the inscription in the cross, indicates that it was intended to read out loud, and this may also suggest that early medieval populations may have taken advantage of the potential of this site as a place of gathering. As explained earlier, this place was capable of sustaining large groups in terms of resources and offered a secluded scene that operated as a natural amphitheatre. In the context of this landscape, reading the inscription on the cross out loud, performing ceremonies or even a mass, may have added power to the political and symbolic statement already made by the actual monument. The nature of the inscription, looking to declare not only the sovereignty of Cyngen's lineage and the rights of his ancestry, but also to commemorate the defeat of their dominant neighbours, must be interpreted as a bold and purposeful exercise by the rulers of Powys. As Edwards has suggested, the emphasis on the origins, genealogy, and history of Cyngen family, as well as the wording of the inscription, may also suggest the use of the monument in royal inauguration ceremonies. ${ }^{79}$

\section{A PLACE FOR SOCIAL INTERACTION}

Other equally powerful reasons may have led to the establishment of such an important monument in the Eglwyseg valley. The Pillar is only few kilometres away from Offa's Dyke and its successor, Wat's Dyke, and from a principal avenue of communication through the Mercian frontier. Therefore, the Pillar needs to be considered within the frontier between disparate Welsh territories and Mercia. Its centrality in terms of the routes of communication, visual properties and geographic location, make this place ideal as a site to gather for trade and exchange and informal meetings as well as legal assembly. ${ }^{80} \mathrm{It}$ would have provided for a large camp and it is situated at the greatest point of connectivity, with access to all key routes of communication north to the Dee. Its direct visual access to Cefn Ucha common (the point with the highest visual index on the cumulative viewshed analysis), which in turn, visually controls not only the entrance to the Vale of Llangollen from the English side, but also all the highest points in the surrounding mountains, would have made communications with the location easy enabling its protection. In this sense, the area of the Pillar may have served as the antechamber into either British or Anglo-Saxon territory, where parties gathering either for political, social, or commercial purposes may have found a place to meet in a contained but well-connected and controlled environment. Interactions in the frontier at the time need not always have been hostile.

An example of this kind of interaction, although later in date, can be found in the Ordinance of the Dunsæte, a 10th- or 11th-century document that records the procedure to regulate contact between the English and the Welsh living on either side of an unnamed river ${ }^{81}$ Although the exact location to which relates is uncertain, is generally accepted that the document makes reference to the River Wye around the Welsh area of Archenfield, southwest of Hereford. ${ }^{82}$ On it, regulations and punishments are established to deal, for 
instance, with disputes regarding cattle along the frontier, and it also stipulates that anyone crossing to the other side of the river should be accompanied by an appointed person from the land he was entering who would take responsibility for supervising the foreigner. The document suggests that territories within the frontier were to some extent guarded, and strategic points in the landscape were crucial in terms of defence and the control traffic and communications along the frontier. Most documents surviving from the same period dealing with both 'sides', make reference to raids and battles, and it is obvious that this document was drafted to manage and avoid conflict no doubt based on prior experience. Despite the uncertainty of both the location and period of the Ordinance, it also testifies that cordial relationships could exist, with reference to people crossing the frontier implications that both groups might have engaged in trading activities. ${ }^{8} 3$ This is also supported by archaeological evidence for imported English metalwork, pottery and coins in Wales, as well as few documents. The Vita Sancti Gundleii refers to an English merchant at the River Usk, and supports the idea that cross-border trading was more common than usually thought. ${ }^{84}$ These documents do not relate to the Llangollen area, but it is not difficult to imagine that places like the Eglwyseg Valley may have served as 'secure' locations where meetings from both parties could take place. The Pillar, serving as a Christian cross, might have functioned not only as a marker and political statement, but a symbol of prestige and identity to which all those gathering there might appeal and identify with.

\section{AN ALTERNATIVE HYPOTHESIS FOR THE PILLAR OF ELISEG}

So far we have put forward a range of ideas regarding the different affordances of this landscape which might have provoked this choice of location for the erection of the Pillar of Eliseg. All our assumptions, in many ways, are predicated on the Pillar being a monument raised by Cyngen to honour his dynasty in a landscape mainly under British control, at least when this part of Wales was not clearly under Mercian overlordship. However, this view conflates the raising of the monument with the inscription, backprojects modern conceptions of what constitutes 'Wales', and does not entertain that those areas immediately to the west of the linear earthworks of Offa's and Wat's dykes as contested lands, under persistent yet different intensities of Mercian domination and influence from the time of Penda onwards. As Ray and Bapty have recently proposed ${ }^{85}$ and Charles-Edwards has also argued, the recovery of Powys as recorded on the Pillar '...may be compared with other periods when Mercian kings displaced local English dynasties', and that 'Similar incidents were to occur in the gth century, when the Mercian overlordship over much of Wales can hardly be denied. ${ }^{86}$ Contrary to Fox's idea of Offa's Dyke as an agreed frontier, successive scholars have proposed that this earthwork, and Wat's Dyke its proposed successor/supplement, defined a frontier zone both to their west and their east. ${ }^{87}$ The political weakness of this area (Powys) after the first half of the gth century, is signalled by the absence of a systematic presence of works of sculpture, indicative perhaps of an absence of sustained patronage. Indeed some parallels in the region indicate increasing influence or power from a Mercian presence. ${ }^{88}$ While acknowledging the importance of the Vale of Llangollen as one of the main gateways across the Mercian frontier, in light of these factors it is reasonable to contend that the Mercians may have actively looked to control this passageway and lands west of the dykes. The narrative on the inscription of the Pillar referring to the triumph of Elise, the campaigns of Coenwulf against Powys in 822, Ecgberth of Wessex in 828 , the later invasions of Wales in 853 , as well as the actual act by 
Cyngen ordering such inscription, all underscore the area as a highly contested zone that may have been in Mercian control, domination, or at least sustained surveillance. ${ }^{89}$

The Pillar has been regarded as a unique monument by Welsh standards, as there is no other monument in Wales with the same characteristics, namely, a free-standing Christian cross with a round shaft, placed on the top of an ancient mound. Although some comparisons between the Pillar and examples of Anglo-Saxon crosses can be made, particularly the round-shaft group of the Peak District, these are traditionally dated later than the Pillar, to the $10^{\text {th }}$ and $11^{\text {th }}$ centuries $A D$, but Bailey identifies a wide distribution of $8^{\text {th }} / 9^{\text {th }}$-century predecessors. $9^{\circ}$ However, there are many parallels to sculpted stone crosses from Northumbria and Mercia. Bearing in mind that the landscape where the Pillar was erected was of great strategic importance, and a contested place which might once have been in an Anglo-Saxon landscape, we need to consider whether the Pillar could have been initially a Mercian monument raised during a campaign or duration of Mercian direct control of lâl, perhaps during the 810 /early 820 s by Coenwulf, and specifically perhaps when the Annales Cambriae cites the English taking the 'kingdom of Powys into their power' in 822. ${ }^{11}$ During the late 8205, when Mercian defeat by the West Saxons at Ellendun, led to a retrenchment of Mercian power, is one plausible context in which Cyngen, as a new ruler recovering land in a fashion akin to his great-grandfather Elise, carved his commemorative inscription on a recently established Mercian monument. This could explain its 'uniqueness', not only in terms of the actual monument, but also the explicit textual references and landscape materialisation of the defeat or even defeats of the Mercians narrated by Cyngen in the inscription. In a landscape where disputes could take on a monumental expression (including both dykes and crosses), and attest to long-standing and profound conflict, taking control over a monument that might have been created under Mercian dominion, would materialise the land's symbolic and actual reconquest and reappropriation. The sense of legitimisation that Cyngen seems to have sought through the championship of the Powysian genealogy and the celebration of the English defeat by his great-grandfather through the unique Latin text speaks to this interpretation. Therefore, although the death of Cyngen in 854/55 in Rome provides a terminus ante quem for the inscription, the monument could have been conceived and erected some decades earlier by the Mercians before being swiftly re-purposed.

While the motives and historical context for the Pillar's carving and inscription might remain hazy, it is fair to question its single-phase creation and recognise that the monument needs to be considered neither 'English' or 'Welsh', but a dynamic elite monument, possibly created over multiple phases by competing dynasties, and deployed to configure senses of place and the past in relation to multiple audiences This study certainly suggests that, as a landmark and a gathering place, the cross and mound was likely utilised and recognised by both British and Anglo-Saxon groups.

\section{CONCLUSIONS}

The study of the landscape of the Pillar is far from concluded. Further work in the immediate environs of the monument is forthcoming, ${ }^{92}$ and there is certainly the potential of exploring the nuanced back-projection of later patterns of land tenure and administration, as well as place-name and textual evidence for assembly places in this landscape. The Pillar's location matches the topographical and archaeological criteria of accessibility, distinctiveness and indications of territorial relationships, identified in recent discussions of early medieval assembly sites elsewhere. ${ }^{93}$ Our analysis supports Edwards'94 
suggestion that the monument might have been an assembly place possibly used, or designed to be used, in royal inauguration. While complementing the work on the Pillar itself by Project Eliseg, this article has sought to situate the landscape as central to the monument's narrative, arguing that the setting of the monument also projected and mediated social memory for a wide range of potential groups living in and traversing its environs. Likewise, if it did serve as a gathering place, it might have not been exclusively to serve Powysian royal interests.

Certainly more archaeological investigations are required in this area, not least in the environs of the Pillar itself and its immediate locality around Valle Crucis Abbey, but also sites like the Iron Age hillfort and later castle of Castell Dinas Brân. Such work would enrich our understanding of the dynamics of the frontier and the Pillar's potential relationship to its environs, as a place of worship, assembly, military muster, seasonal fairs and other activities. It might be the case that lookout points and an accompanying beacon system, operated by Powysian authorities (or indeed in fluctuating possession between Powys and Mercia), could have managed visually what the Mercians attempted to do with linear earthworks, to control and regulate movement in this contested landscape. This might have utilised key pre-existing hillfort sites and/or high-points in the environs of the Pillar. ${ }^{95}$ In all these regards, despite the martial nature of its commemorative text on the Pillar, we need to think simultaneously about patterns of transhumant farming practices, hunting and markets, as well as musters for war, when considering the potential multifunctional character of the Pillar of Eliseg in its landscape context.

Writing about the early medieval Mercian border with Wales, David Hill ${ }^{6}$ argued that there is no evidence in terms of trade and commerce across the frontier, and because it has proved so far that there were probably few gateways in Offa's dyke, this leaves '...the impression that there was little or no traffic across those lines'. However, as demonstrated by the viewsheds from Treuddyn and Hope Mountain, close to the northern end of Offa's Dyke, it is possible to visually control the modern frontier between England and Wales and the corridor of routes running between and along the dykes from the Dee to the Severn. This could mean that, although potentially highly controlled, it is entirely possible that traffic did move along the border, as the events described in the later Ordinance of the Dunsæte seem to imply. We do not have any direct surviving material evidence, but we might envisage that agricultural products and food might have been the main sources of exchange. ${ }^{97}$ Furthermore, the area of the Pillar, due to its closeness to one these few gateways, its location in one of the main natural corridors, and its protected nature, may have provided one of the places where these interactions could happen. The location was protected visually from all directions and might have worked as a safe gathering point for social and political events, as well acts of worship.

Appreciation of the early medieval frontier landscape is enhanced by understanding the Pillar of Eliseg as a monument related to routines of movement and strategies of surveillance, as well as a place rooted in the ancient, mythologised past. The relationship between the monument's text and its landscape context was the pivot around which the monument may have been intended to forge identities and social memories.

\section{ACKNOWLEDGEMENTS}

We are grateful to the HER of Clwyd-Powys Archaeological Trust for supplying details of archaeological sites in the vicinity of the Pillar of Eliseg. We would like to thank Rhiannon Comeau, Nancy Edwards, Dai Morgan Evans, Tim Malim, Keith Ray, Marion Shiner, Gary 
Robinson and Rachel Swallow for guidance and critical comments. All arguments and errors remain the authors' responsibility.

The research leading to these results has received funding from the European Research Council under the European Union's Seventh Framework Programme (FP/20072013) ERC grant 'The Past in its Place' (agreement no 284085).

\section{BIBLIOGRAPHY}

Back Danielsson, I-M 2015, 'Walking down memory lane: rune-stones as mnemonic agents in the landscapes of late Viking-Age Scandinavia', in Williams et al 2015a, 62-86.

Baker, J 2011, 'Warriors and watchmen: place names and Anglo-Saxon civil defence', Medieval Archaeol 55, 258-67.

Baker, J and Brookes, S 2015a, 'Identifying outdoor assembly sites in early medieval England', J Field Archaeol 40:1, 3-21.

Baker, J and Brookes, S 2015b, 'Signalling intent: beacons, lookouts and military communications', in M C Hyer and G R Owen-Crocker (eds), 216-34.

Bennett, J 1995, Minera: Lead Mines and Quarries, Wrexham: Wrexham Maelor Borough Council.

Besly, E 2006, 'Few and far between: mints and coins in Wales to the middle of the thirteenth century', in B J Cook, G Williams and M Archibald (eds), Coinage and History in the North Sea World, C AD 500-1250: Essays in Honour of Marion Archibald, Leiden: Brill, 701-20.

Bradley, R 1987, 'Time regained: the creation of continuity', J Brit Archaeol Assoc 140:1, 117.

Brookes, S 2007, 'Walking with Anglo-Saxons: landscapes of the living and landscapes of the dead in early Anglo-Saxon Kent', Anglo-Saxon Stud Hist Archaeol 14, 143-53.

Brookes, S 2013, 'Mapping Anglo-Saxon civil defence', in J Baker, S Brookes and A Reynolds (eds), Landscapes of Defence in Early Medieval Europe, Turnhout: Brepols, 39-64.

Charles-Edwards, T M 2004, 'Gorsedd, dadl, and llys: assemblies and courts in medieval Wales', in Pantos and Semple, 95-108.

Charles-Edwards, T M 2013, Wales and the Britons, 350-1064, The History of Wales vol 1, Oxford: Oxford University Press.

Clwyd-Powys Archaeological Trust, 2015a, CPAT Historic Environment Record, $<$ http://www.cpat.org.uk/> [accessed 16 Jun 2015].

Clwyd-Powys Archaeological Trust, 2015b, Historic Landscape Characterisation: Vale of Llangollen and Eglwyseg, <http://www.cpat.org.uk/projects/longer/histland/llangoll/vlintr.htm> [accessed 13 Jan 2015].

Coatsworth, E 2015, 'Landmarks of faith: crosses and free-standing stones', in M C Hyer and G R Owen-Crocker (eds), 117-36.

Comeau, R 2014, 'Bayvil in Cemais: an early medieval assembly site in south-west Wales?' Medieval Archaeol 58, 270-84.

Conolly, J and Lake, M 2006, Geographical Information Systems in Archaeology, Cambridge: Cambridge University Press. 
Contreras, F, Fargas, M and Melero, F J (eds) 2010, Fusion of Cultures. Proceedings of the 38th Annual Conference on Computer Applications and Quantitative Methods in Archaeology, Granada, Spain, April 2010, Brit Archaeol Rep Int Ser 2494.

Crouwers, I 2015, 'The biographies and audiences of late Viking-Age and medieval stone crosses and cross-decorated stones in western Norway', in Williams et al 2015a, 149-82.

Darvill, T 2004, 'Tynwald Hill and the 'things' of power', in Pantos and Semple, 217-33.

Davies, W 1982, Wales in the Early Middle Ages, Leicester: University of Leicester Press.

Earl, G, Sly, T, Chrysanthi, A, Murrieta-Flores, P, Papadopoulos, C, Romanowska, I, and Wheatley, D (eds) 2013, Archaeology in the Digital Era: Papers from the 40 th Annual Conference of Computer Applications and Quantitative Methods in Archaeology (CAA), Southampton, 26-29 March 2012, Amsterdam: Amsterdam University Press.

Edwards, J F 1987, The Transport System of Medieval England and Wales - A Geographical Synthesis, (unpubl PhD thesis, University of Salford).

Edwards, N 2001, 'Early-medieval inscribed stones and stone sculpture in Wales: context and function', Medieval Archaeol 49, 15-39.

Edwards, N 2008, 'The Pillar of Eliseg', in D H Evans, Valle Crucis Abbey, revs edit, Cadw: Welsh Assembly Government, 53-6.

Edwards, N 2009, 'Rethinking the Pillar of Eliseg', Antiq J 89, 143-77.

Edwards, N 2013a, Corpus of Early Medieval Inscribed Stones and Stone Sculpture in Wales, Volume 3, North Wales, Cardiff: University of Wales Press.

Edwards, N 2013b, The early medieval sculpture of North Wales: context, wealth and patronage, in J Hawkes (ed), Making Histories. Proceedings of the Sixth International Conference on Insular Art, York 2011, Donington: Shaun Tyas, 50-64.

Edwards, N, Robinson, G, Williams, H and Evans, D M 2011, 'The Pillar of Eliseg, Llantysilio, incomplete inscribed cross and cairn', Archaeol Wales 50, 57-9.

Edwards, N, Robinson, G and Williams, H 2013, 'Llantysilio, The Pillar of Eliseg', Archaeol Wales 52, 199-201.

Edwards, N, Robinson, G and Williams, H 2014, 'Llantysilio, The Pillar of Eliseg', Archaeol Wales 53, 186-9.

Edwards, N, Robinson, $\mathrm{G}$ and Williams, $\mathrm{H}$ forthcoming, The Pillar of Eliseg-A Monument Biography from Prehistory to the Present, Cardiff: University of Wales Press.

Fitzpatrick, E. 2012. Formaoil na Fiann: hunting preserves and assembly places in Gaelic Ireland, Proceedings of the Harvard Celtic Colloquium 32, 95-118.

Fitzpatrick, E, 2015, Assembly places and elite collective identities in medieval Ireland, Journal of the North Atlantic Special Vol. 8: 52-68

Fox, C 1955, Offa's Dyke: A Field Survey of the Western Frontier-Works of Mercia in the Seventh and Eighth Centuries $A D$, London: Oxford University Press.

Frachetti, M D 2006, 'Digital archaeology and the scalar structure of pastoral landscapes: modeling mobile societies of prehistoric central Asia', in P Daly and T L Evans (eds), Digital Archaeology: Bridging Method and Theory, London: Routledge, 12847.

Frachetti, M D 2008, 'Variability and dynamic landscapes of mobile pastoralism in ethnography and prehistory', in H Barnard and W Wendrich (eds), The Archaeology of Mobility. Old World and New World Nomadism, Los Angeles: Cotsen Institute of Archaeology, University of California, 366-92.

Frieman, C, and Gillings, M 2007, Seeing Is Perceiving? World Archaeology $39: 1,4-16$. 
Gelling, M 1992, The West Midlands in the Early Middle Ages, Leicester: Leicester University Press.

Gillings, M, and Wheatley, D 2001, 'Seeing Is Not Believing: Unresolved Issues in Archaeological Visibility Analysis'. In On the Good Use of Geographical Information Systems in Archaeological Landscape Studies. Proceedings of the COST G2 Working Group 2 Round Table. Luxembourg: Office for Official Publications of the European Communities, 25-36.

Guth, P 2009, 'Incorporating vegetation in viewshed and line-of-sight algorithms', in ASPRS/Mapps 2009 Specialty Conference, San Antonio, Texas, November 16-19, 2009: DIGITAL MAPPING: From Elevation to Information. 7 page aper on CD-ROM. http://www.asprs.org/a/publications/proceedings/sanantonioog/Guth.pdf [accessed?]

Hankinson, R 2002, The Short Dykes of Mid and North-East Wales, CPAT, Report 700, < http://www.cpat.org.uk/resource/reports/cpat70o.pdf > [accessed 9 Jan 2017]

Hall, M 2015, 'Lifeways in stone: memories and matter-reality in early medieval sculpture from Scotland', in Williams et al 2015a, 182-215.

Hayes, $L$ and Malim, T 2008, 'The date and nature of Wat's Dyke: a reassessment in the light of recent investigations at Gobowen, Shropshire', in S Crawford and H Hamerow (eds), Anglo-Saxon Stud Archaeol Hist 15, 147-79.

Herzog, I 2010, 'Theory and practice of cost functions', in F Contreras, M Fargas and F J Melero (eds), 375-82.

Hill, D 2000, 'Offa's Dyke: pattern and purpose', Antiq J 80, 195-206.

Hill, D 2001, 'Mercians: the dwellers on the boundary', in M P Brown and C A Farr (eds), Mercia: An Anglo-Saxon Kingdom in Europe, London: Bloomsbury, 173-82.

Hill, D and Worthington, M 2003, Offa's Dyke: History and Guide, Stroud: Tempus.

Hindle, P 2015, 'Roads and tracks in Anglo-Saxon England', in M C Hyer and G R OwenCrocker (eds), 37-49.

Hyer, M C and Owen-Crocker, G R (eds), The Material Culture of the Built Environment in the Anglo-Saxon World, Liverpool: Liverpool University Press.

Ingram, J (trans), 1912a, The Annales Cambriae (The Annals of Wales), London: Everyman. Insley, C 2012, 'The family of Wulfric Spott: an Anglo-Saxon Mercian Marcher dynasty?', in

D Roffe (ed), The English and Their Legacy, 900-1200: Essays in Honour of Ann Williams, Woodbridge: Boydell, 115-28.

Kightly, C 2003, Dinas Brân, Langollen/Castell Dinas Brân, Llangollen, Ruthin: Denbighshire County Council.

Kirby, D P 2002, The Earliest English Kings, London: Routledge.

Kirton, J 2015, 'Locating the Cleulow Cross: materiality, place and landscape', in Williams et al 2015a, 35-61.

Lindsay, J B 2014, 'The Whitebox geospatial analysis tools project and open-access GIS', in J Drummond (ed), Proceedings of the GIS Research UK 22nd Annual Conference, University of Glasgow 16-18 April 2014, Glasgow: The University of Glasgow, 10-19.

Lake, M, and Woodman, P 2003, Visibility Studies in Archaeology: A Review and Case Study, Environment and Planning B 30: 5, 689-707.

Llobera, M 2007a, 'Modeling visibility through vegetation', International J Geographl Informat Sci 21:7, 799-810.

Llobera, M 2007b, 'Reconstructing visual landscapes', World Archaeol 39:1, 51-69. 
Lock, G R (ed) 2000, Beyond the Map: Archaeology and Spatial Technologies, Amsterdam: IOS.

Llobera, M, and Sluckin, T 2007, Zigzagging: Theoretical Insights on Climbing Strategies, Journal of Theoretical Archaeology 249, 206-2017.

Malim, T 2007 'The origins and design of linear earthworks in the Welsh Marches', Landscape Enquires, Proc Clifton Antiq Club 8, 13-32.

Mlekuž, D 2010, 'Time geography, GIS and archaeology', in F Contreras, M Fargas and F J Melero (eds), 359-65.

Mlekuž, D 2014, 'Approaching past movement: time to move a little further?', in S Polla and $P$ Verhagen (eds), 5-22.

Molyneaux, G 2011, 'The ordinance concerning the Dunsæte and the Anglo-Welsh frontier in the late tenth and eleventh centuries', Anglo-Saxon Engl 40, 249-72.

Murrieta-Flores, P 2012, 'Understanding human movement through spatial technologies. The role of natural areas of transit in the late prehistory of south-western Iberia', Trabajos Prehist 69:1, 103-22.

Murrieta-Flores, P 2013, 'Space and temporality in herding societies: exploring dynamics of movement during Iberian late Prehistory', in S Souvatzi and A Hadji (eds) Space and Time in Mediterranean Prehistory, London: Routledge, 196-213.

Murrieta-Flores, P 2014, 'Developing computational approaches for the study of movement: the impact of visibility in terrestrial navigation during lberian late prehistory', in S Polla and P Verhagen (eds), 99-132.

Noble, F 1983, Offa's Dyke Reviewed, (ed. M. Gelling) Oxdford: Brit Archaeol Rep Brit Seri, 114 .

Pantos, A and Semple, S (eds) 2004, Assembly Places and Practices in Medieval Europe, Dublin: Four Courts.

Polla, S and Verhagen, P (eds) 2014, Computational Approaches to the Study of Movement in Archaeology: Theory, Practice and Interpretation of Factors and Effects of Long Term Landscape Formation and Transformation, Berlin: De Gruyter.

Pratt, D 1995, 'Valle Crucis Abbey, 1606', Clwyd Hist 34, $23-7$.

Ray, K and Bapty, I 2016, Offa's Dyke. Landscape and Hegemony in Eighth-Century Britain, Oxford: Oxbow.

Redknap, M 2007, 'Crossing boundaries - stylistic diversity and external contacts in early medieval Wales and the March: reflections on metalwork and sculpture', Cambrian Medieval Celtic Stud 53/54, 23-86.

Reynolds, A and Langlands, A 2011, 'Travel as communication: a consideration of overland journeys in Anglo-Saxon England', World Archaeol 43:3, 410-27.

Schneider, K and Robbins, P 2009, GIS and Mountain Environments, Geneva: UNITAR.

Seaman, A. 2016. Defended settlement in early medieval Wales: problems of presence, absence and interpretation, in N. Christie and H. Herold (eds) Fortified Settlements in Early Medieval Europe: Defended Communities of the $8^{\text {th }}-10^{\text {th }}$ Centuries, Oxford: Oxbow, 37-52

Semple, S 2013. Perceptions of the Prehistoric in Anglo-Saxon England: Religion, Ritual and Rulership in the Landscape, Oxford: Oxford University Press.

Semple, S and Sanmark, A 2013, Assembly in north west Europe: collective concerns for early societies? European J Archaeol 16:3, 518-42

Sherratt, G 2000, An Illustrated History of Llangollen, Llangollen: Ceiriog Press. 
Silvester, R J and Evans, J W 2009, Identifying the mother churches of north-east Wales, in N. Edwards (ed.) The Archaeology of the Early Medieval Celtic Churches, The Society for Church Archaeology Monograph 1, Leeds: Maney, 21-40

Silvester, R J and Hankinson, R 2002, The Short Dykes of Mid and North-East Wales, CPAT, Rep 458. <http://www.cpat.org.uk/resource/reports/cpat70o.pdf> [Accessed 9 Jan 2017]

Simpson, W.T. 1853, History of Llangollen and its vicinity, Llangollen: David Roberts, Bridge Street.

Stewart, A J 1998, 'Fast horizon computation at all points of a terrain with visibility and shading applications', IEEE Trans Visualization Computer Graphics 4:1, 82-93.

Swallow, R 2016, 'Cheshire Castles of the Irish Sea cultural zone' Archaeol J 173:2, 288-341.

Tabik, S, Cervilla, A R, Zapata, E and Romero, L F 2015, 'Efficient data structure and highly scalable algorithm for total-viewshed computation', IEEE J Selected Topics Applied Earth Observations Remote Sensing 8:1, 304-10.

Tabik, S, Romero, L F and Zapata, E L 2011, 'High-performance three-horizon composition algorithm for large-scale terrains', Int J Geogr Informat Sci 25:4, 541-55.

Tong, J, Evans, S, Williams, H, Edwards, N and Robinson, G 2015, 'Vlog to death: Project Eliseg's video-blogging', Internet Archaeol 39, $<$ http://intarch.ac.uk/journal/issue39/3/toc.html> [9 $9^{\text {th }}$ January 2017

Verhagen, P 2010, 'On the road to nowhere? Least cost paths and the predictive modelling perspective', in F Contreras, M Fargas and F J Melero (eds), 439-42.

Wheatley, D 2014, 'Connecting Landscapes with Built Environments: Visibility Analysis, Scale and the Senses', in E Paliou,U Lieberwirth and S Polla (eds) Spatial Analysis and Social Spaces: Interdisciplinary Approaches to the Interpretation of Historic and Prehistoric Built Environments, Boston: De Gruyter, 115-34.

Wheatley, D and Gillings, M 2002, Spatial Technology and Archaeology: The Archaeological Applications of GIS, London: Taylor and Francis.

Wheatley, D 1995, 'Cumulative viewshed analysis: a GIS-based method for investigating intervisibility, and its archaeological application', in G R Lock and Z Stančič (eds), Archaeology and Geographical Information Systems: A European Perspective, London: Routledge, 171-85.

Wheatley, D W, Sanjuán, L G, Murrieta-Flores, P A and Pérez, J M 2010, 'Approaching the landscape dimension of the megalithic phenomenon in Southern Spain', Oxford J Archaeol, 29:4, 387-405.

Williams, D H 1990, Atlas of Cistercian Landscapes in Wales, Cardiff: University of Wales Press.

Williams, H 2006, Death and Memory in Early Medieval Britain, Cambridge: Cambridge University Press.

Williams, H 2011, 'Remembering elites: early medieval stone crosses as commemorative technologies', in L Boye, P Ethelberg and L Heidemann Lutz et al (eds), Arkæologi $i$ Slesvig/Archäologie in Schleswig. Sonderband 'Det 61. Internationale Sachsensymposion 2010' Haderslev, Danmark, Neumünster: Wachholtz, 13-32.

Williams, H 2016, "'Clumsy and illogical"? Reconsidering the West Kirby hogback', Antiq J 96, 69-100.

Williams, H, Kirton, J and Gondek, M (eds) 2015a, Early Medieval Stone Monuments: Materiality, Biography, Landscape, Woodbridge: Boydell and Brewer. 
Williams, H, Kirton, J and Gondek, M 2015b, 'Introduction: stones in substance, space and time', in Williams et al 2015a, 1-34.

Williams, $\mathrm{H}$ and Murrieta-Flores, $\mathrm{P}$ forthcoming, Dykes beyond defence: seeing and shaping the landscape of the Mercian frontier.

Williams, H, Rundkvist, M and Danielsson, A 2010, 'The landscape of a Swedish boat-grave cemetery', Landscapes 11:1, 1-24.

Worthington, M 1997, 'Wat's Dyke: an archaeological and historical enigma', Bull John Rylands Univ Library Manchester 79:3, 177-96.

Worthington Hill, M and Greig, E 2015, 'Boundaries and walls', in M C Hyer and G R OwenCrocker (eds), 162-80.

\section{LIST OF FIGURE CAPTIONS}

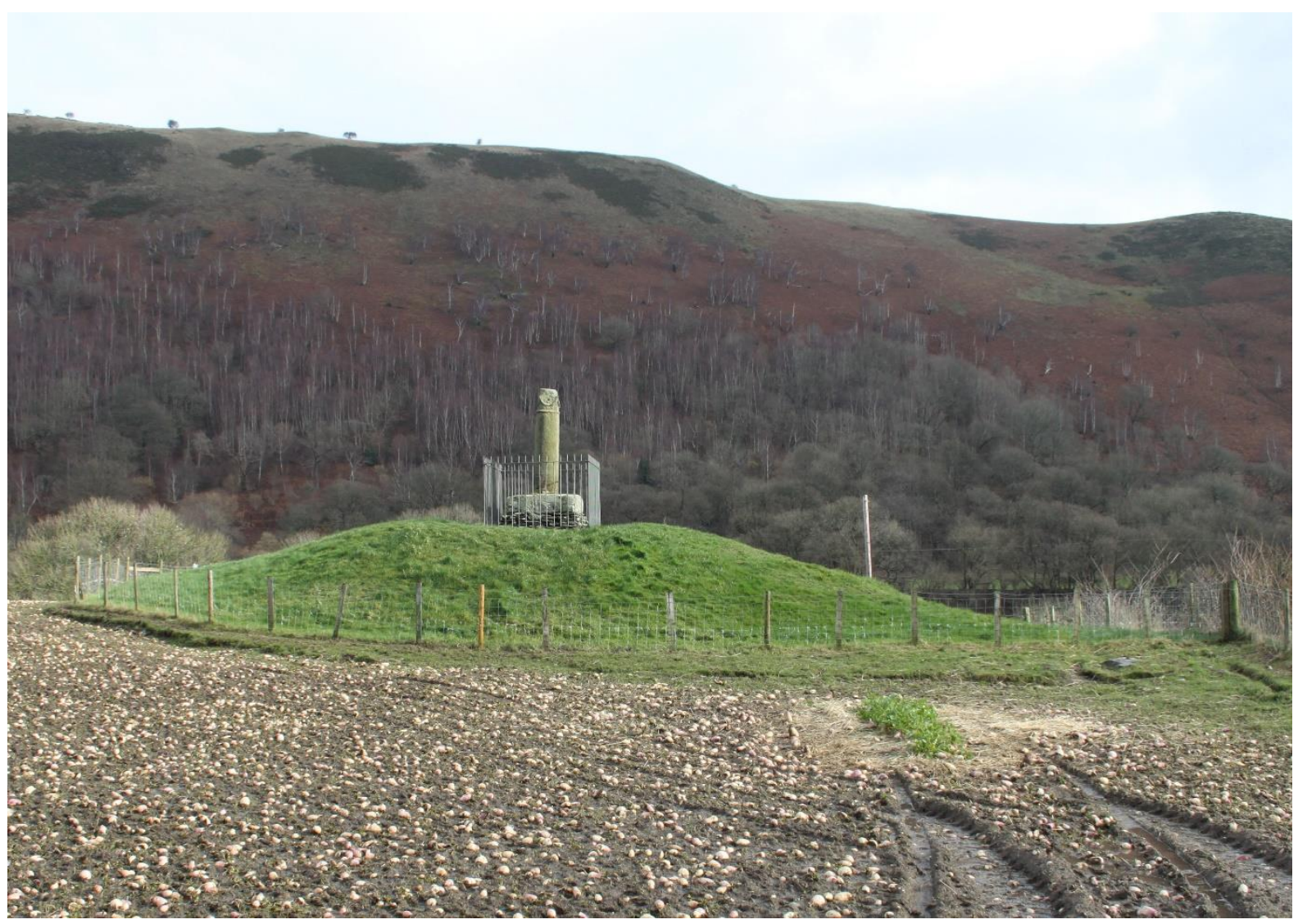

FIG 1

The Pillar of Eliseg from the west. Photograph by Howard Williams. 


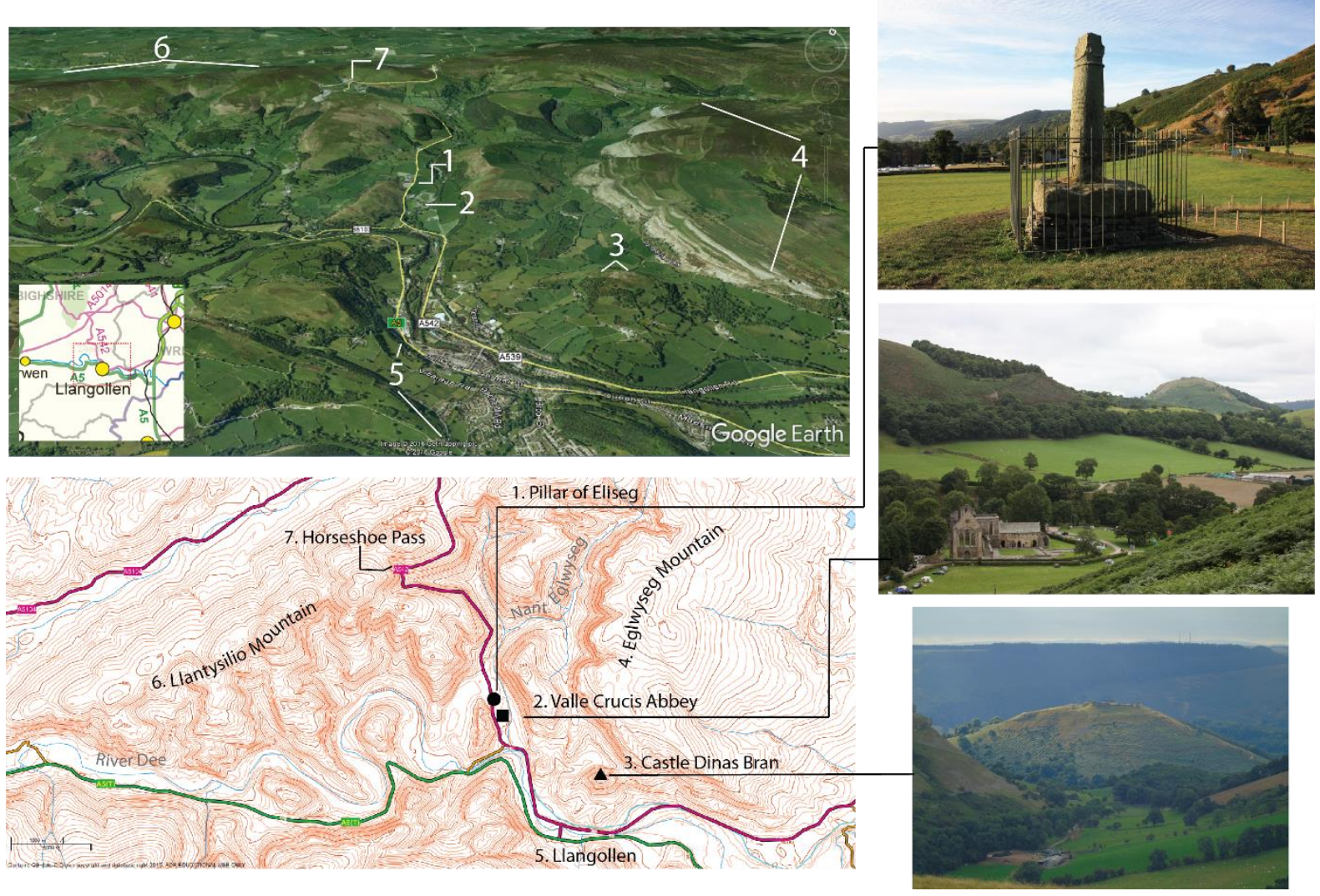

FIG 2

The Location of the Pillar of Eliseg. Drawing by Patricia Murrieta-Flores. @Base map Crown Copyright and Database Right [2012]. An Ordnance Survey Edina supplied service. 


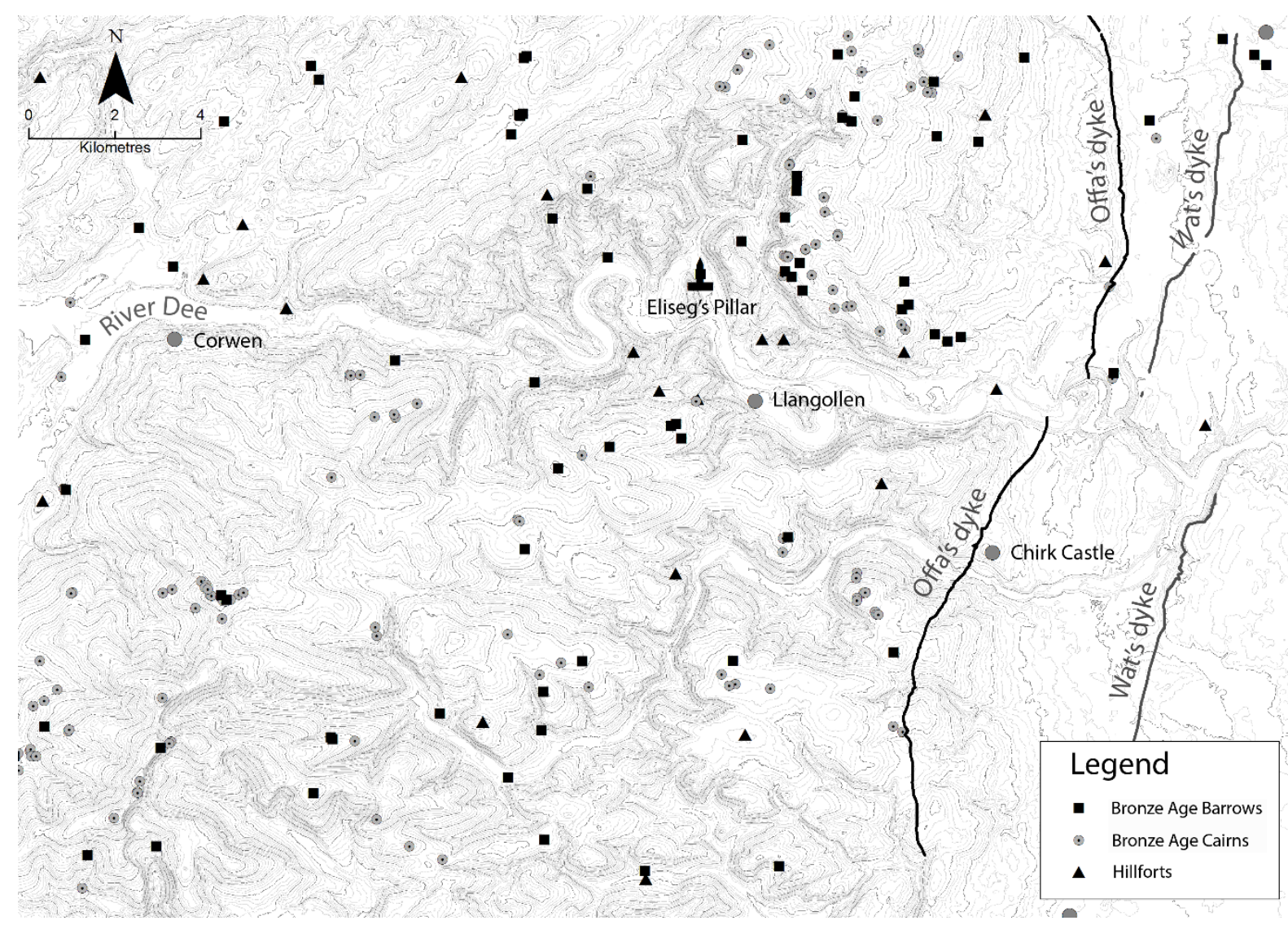

FIG 3

The principal types of standing ancient monuments in the environs of the Pillar of Eliseg and the Vale of Llangollen, incorporating data supplied by Clwyd-Powys Archaeological Trust. Drawing by Patricia Murrieta-Flores. (C) Base map Crown Copyright and Database Right [2012]. An Ordnance Survey Edina supplied service. 


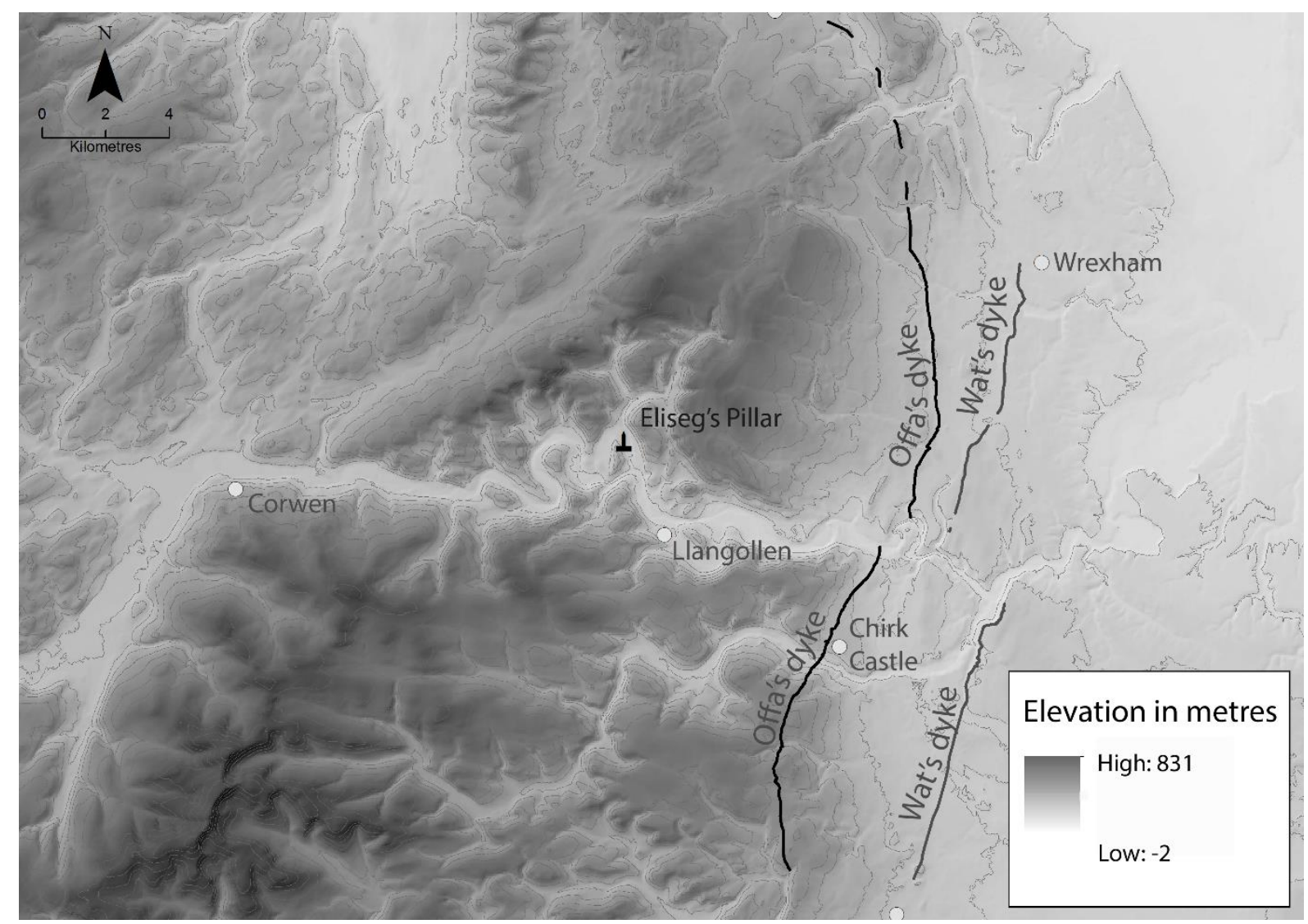

FIG 4

The topography of the wider landscape around the Pillar of Eliseg. Drawing by Patricia Murrieta-Flores. ( Base map Crown Copyright and Database Right [2012]. An Ordnance Survey Edina supplied service. 


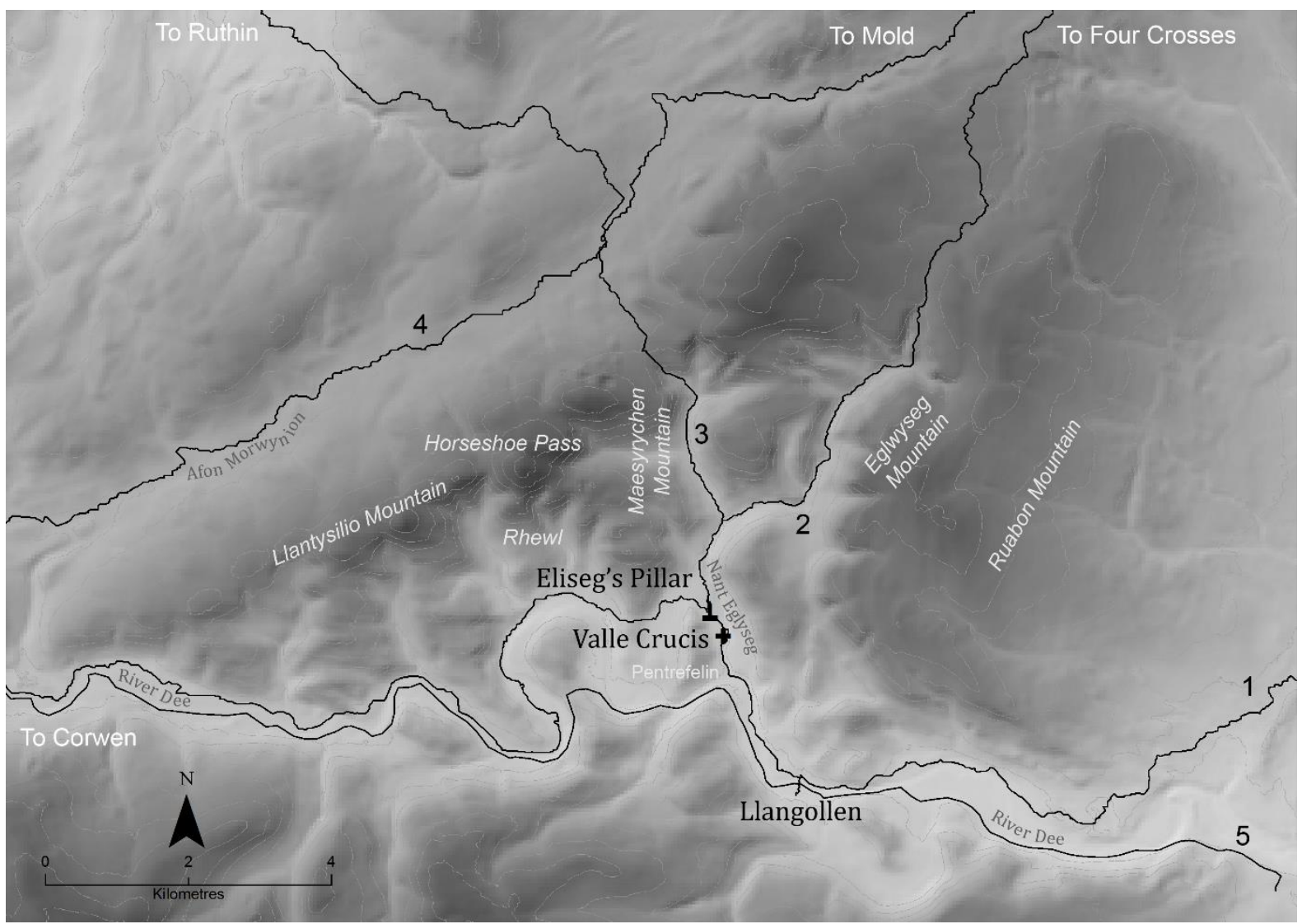

FIG 5

Main natural corridors identified giving access to the Vale of Llangollen. Drawing by Patricia Murrieta-Flores. Base map Crown Copyright Database Right [2012]. An Ordnance Survey Edina supplied service. 


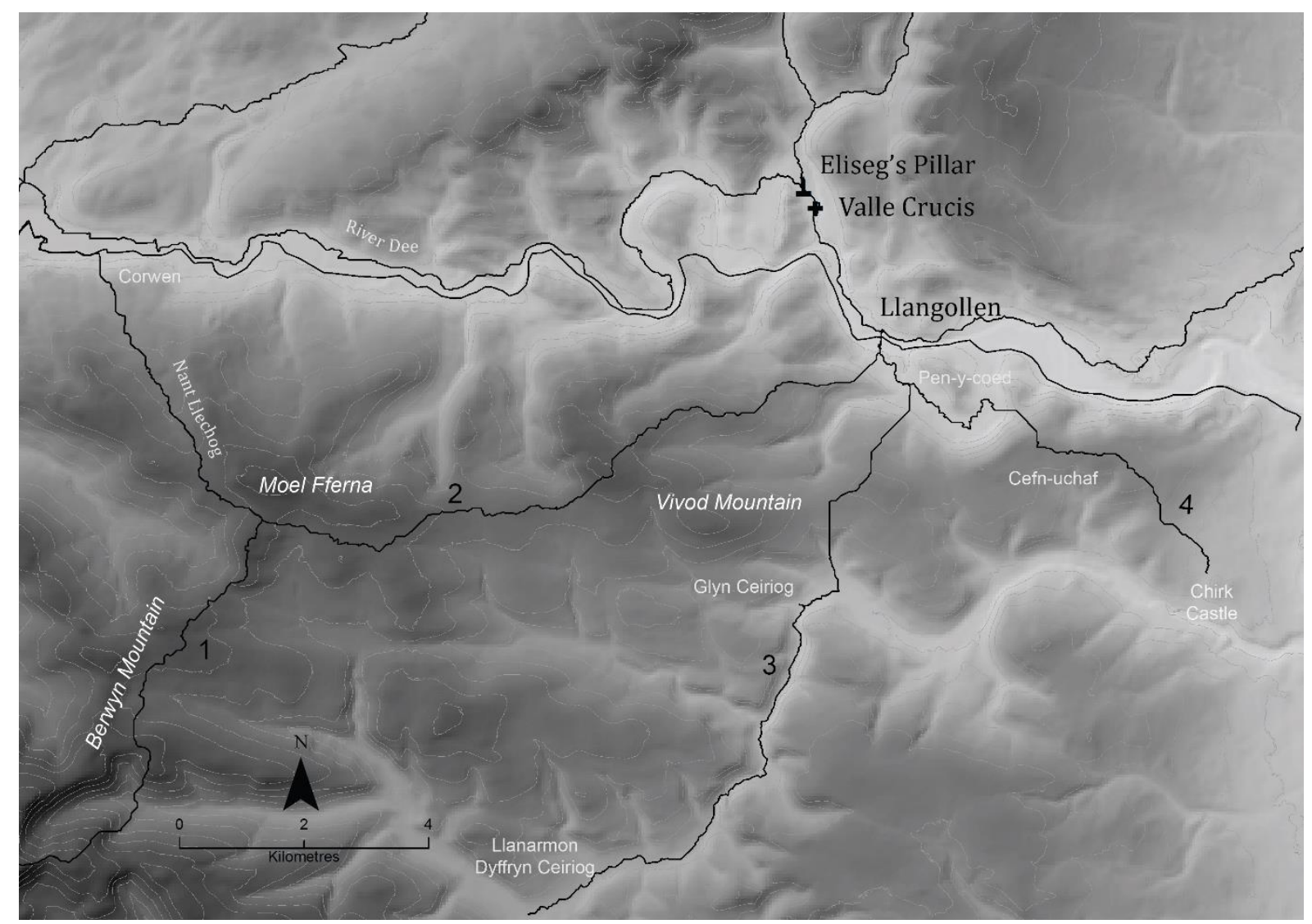

FIG 6

Main natural corridors identified to the south of the Dee. Drawing by Patricia MurrietaFlores. Base map Crown Copyright and Database right [2012]. An Ordnance Survey Edina supplied service. 


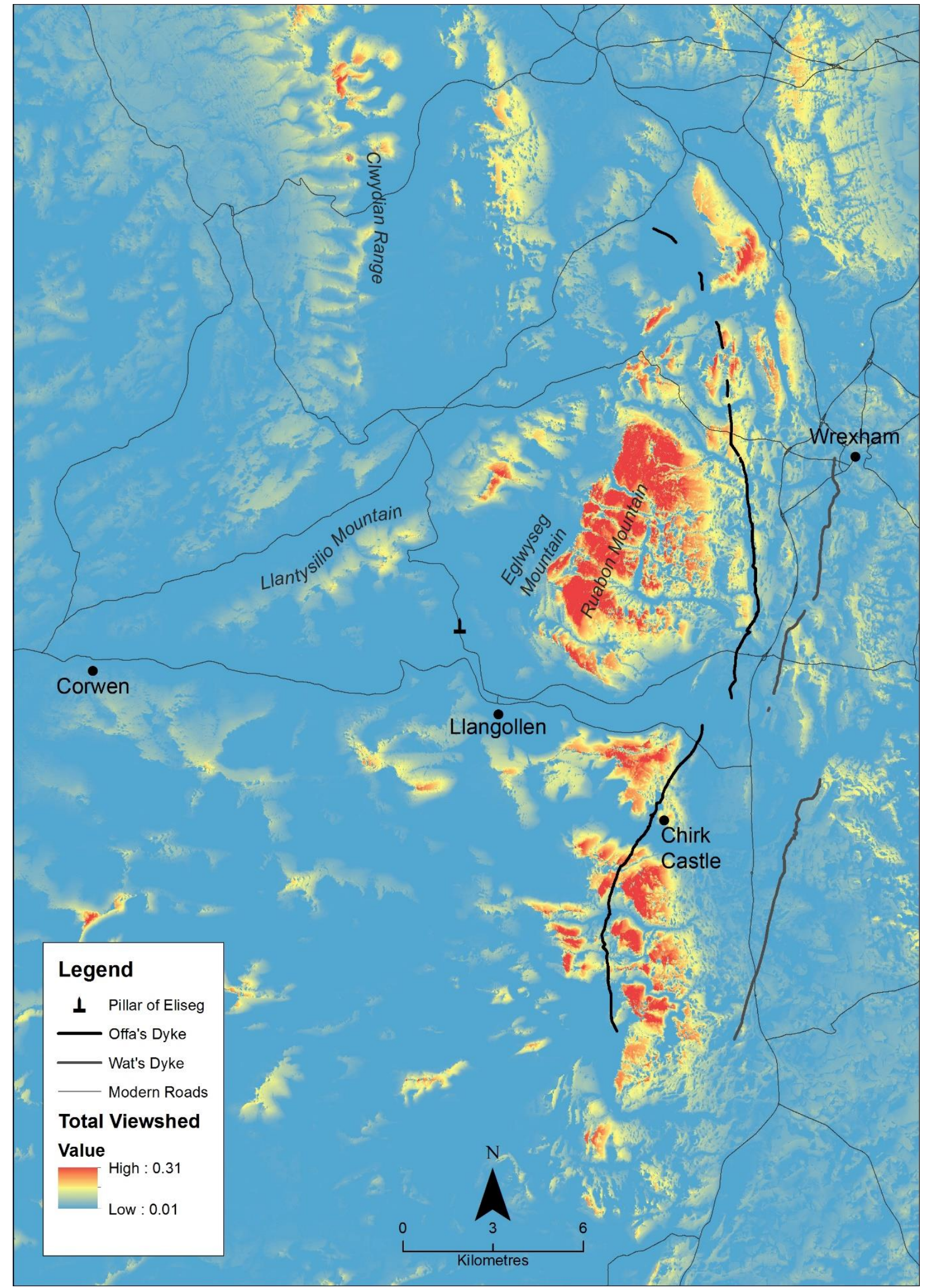

FIG 7

Total Viewshed Analysis around the Pillar of Eliseg. Drawing by Patricia Murrieta-Flores. Base map Crown Copyright and Database Right [2012]. An Ordnance Survey Edina supplied service. 


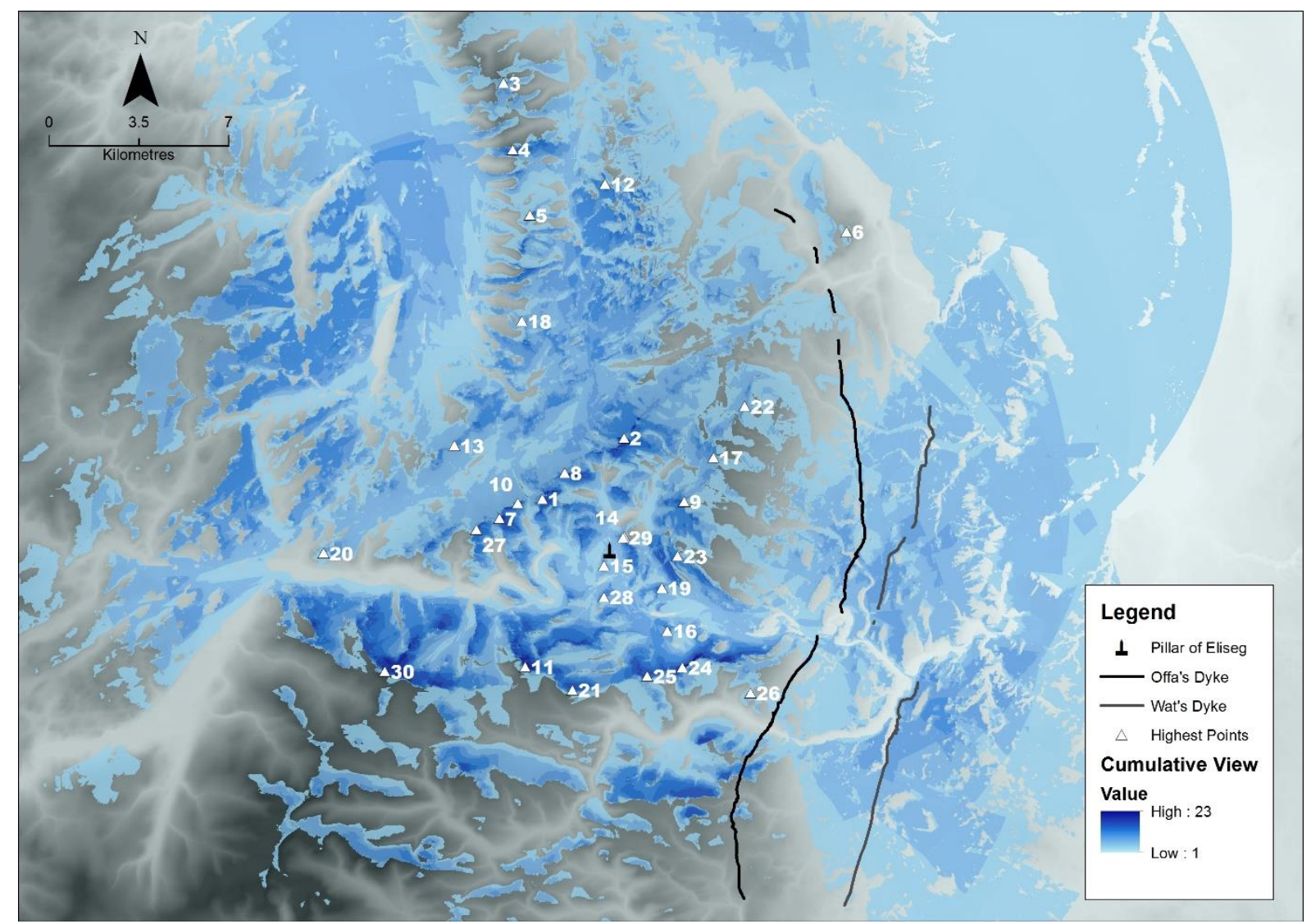

FIG 8

Cumulative Viewshed around the Pillar of Eliseg. Drawing by Patricia Murrieta-Flores. Base map Crown Copyright and Database Right [2012]. An Ordnance Survey Edina supplied service.

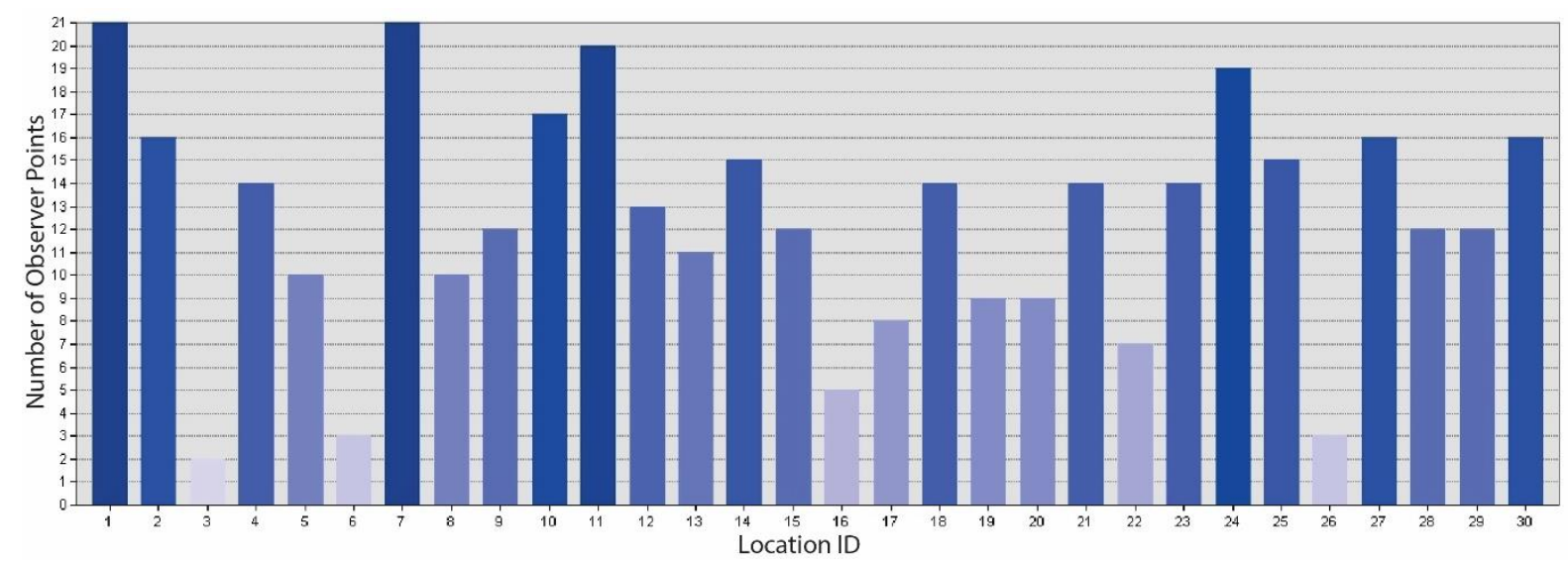

FIG 9

Locations visible from each observer point calculated (see FIG 6). Drawing by Patricia Murrieta-Flores. Base map Crown Copyright and Database Right [2012]. An Ordnance Survey Edina supplied service. 


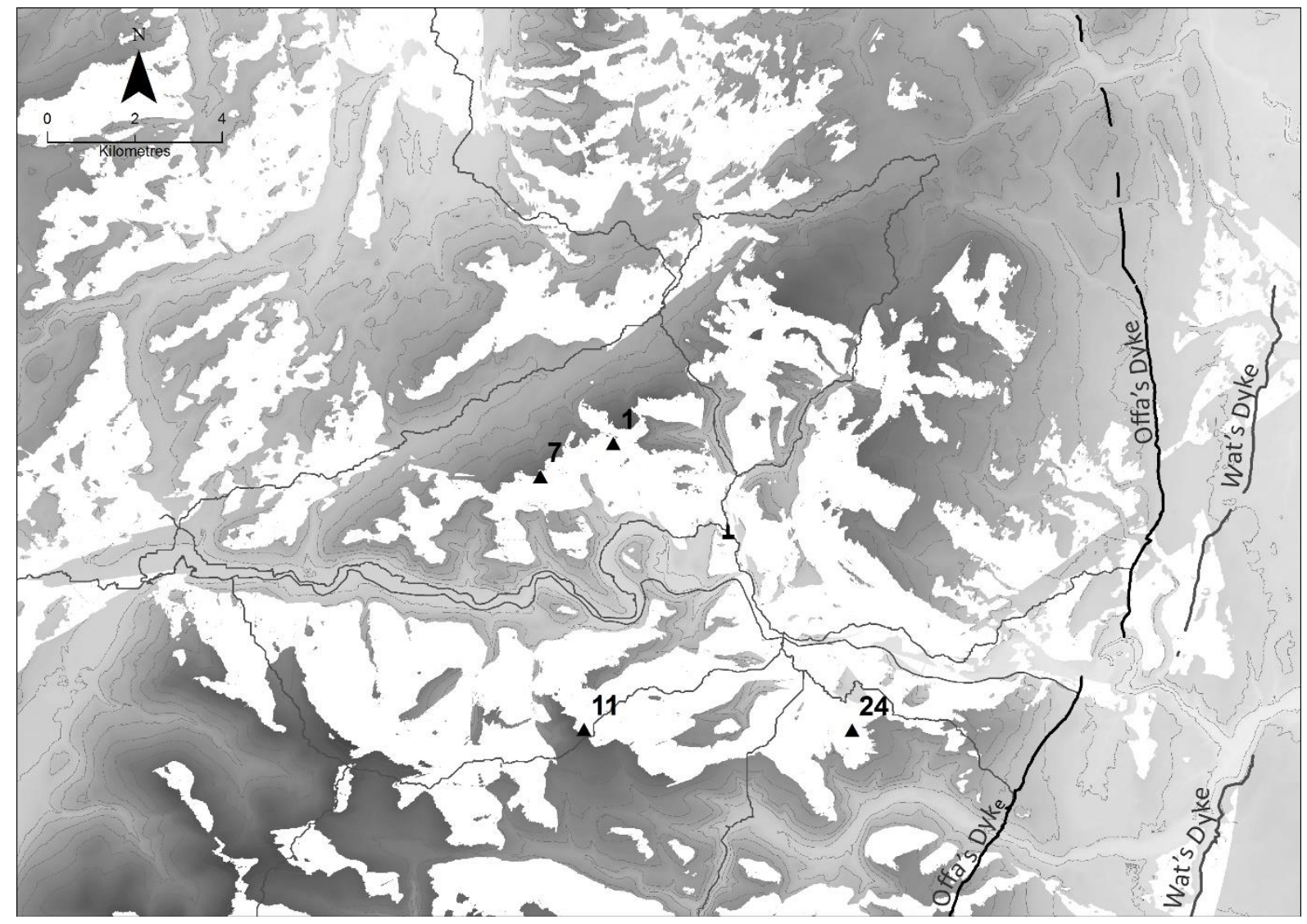

FIG 10

In white the visual area covered by points $1,7,11$ and 24, demonstrating that only few points are needed to cover the natural routes of entrance into the Vale of Llangollen. Drawing by Patricia Murrieta-Flores. Base map Crown Copyright and Database Right [2012]. An Ordnance Survey Edina supplied service. 


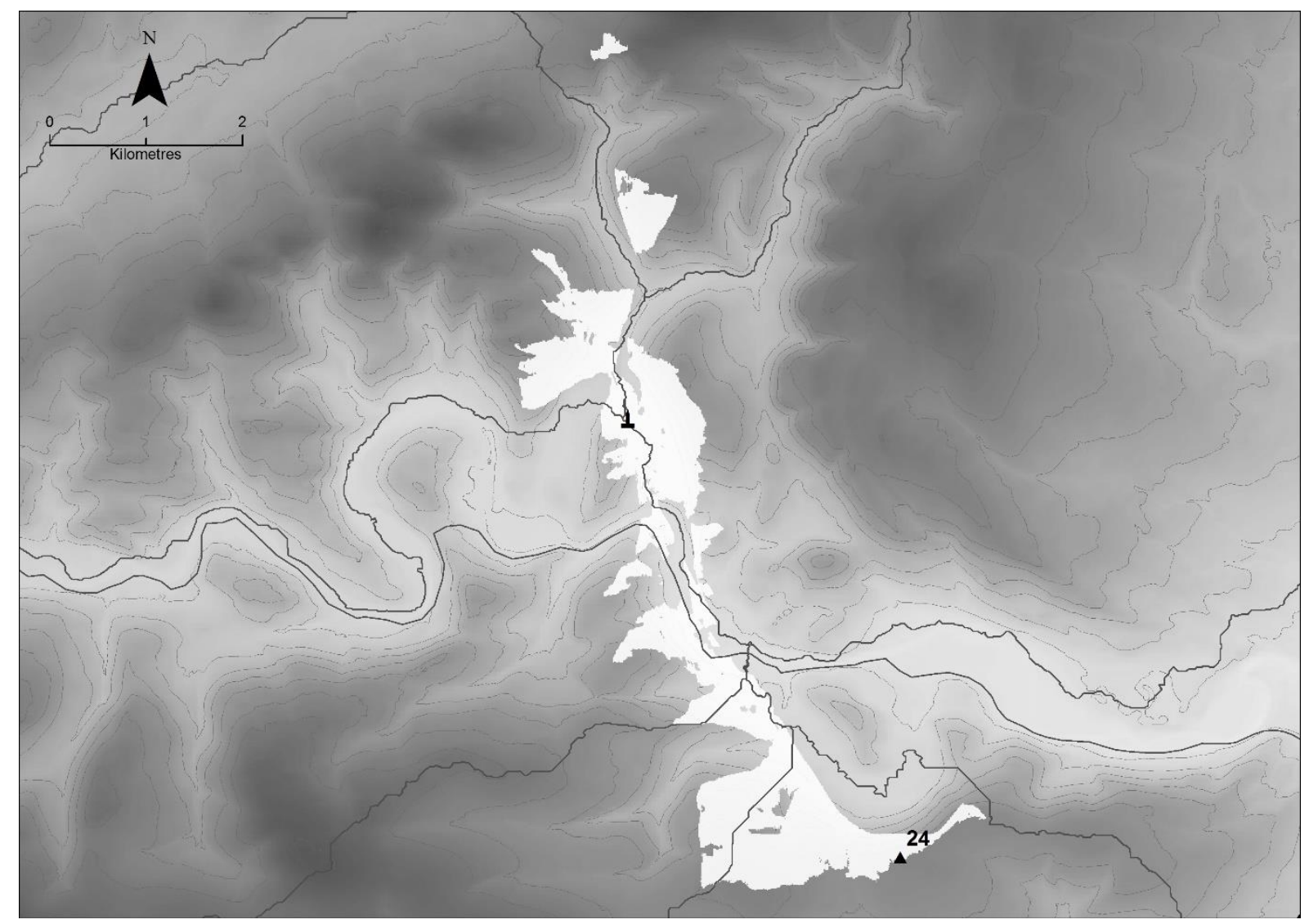

FIG 11

Viewshed from the Pillar of Eliseg and its relation to Cefn Ucha Common (location 24). Drawing by Patricia Murrieta-Flores. Base map Crown Copyright and Database Right [2012]. An Ordnance Survey Edina supplied service. 


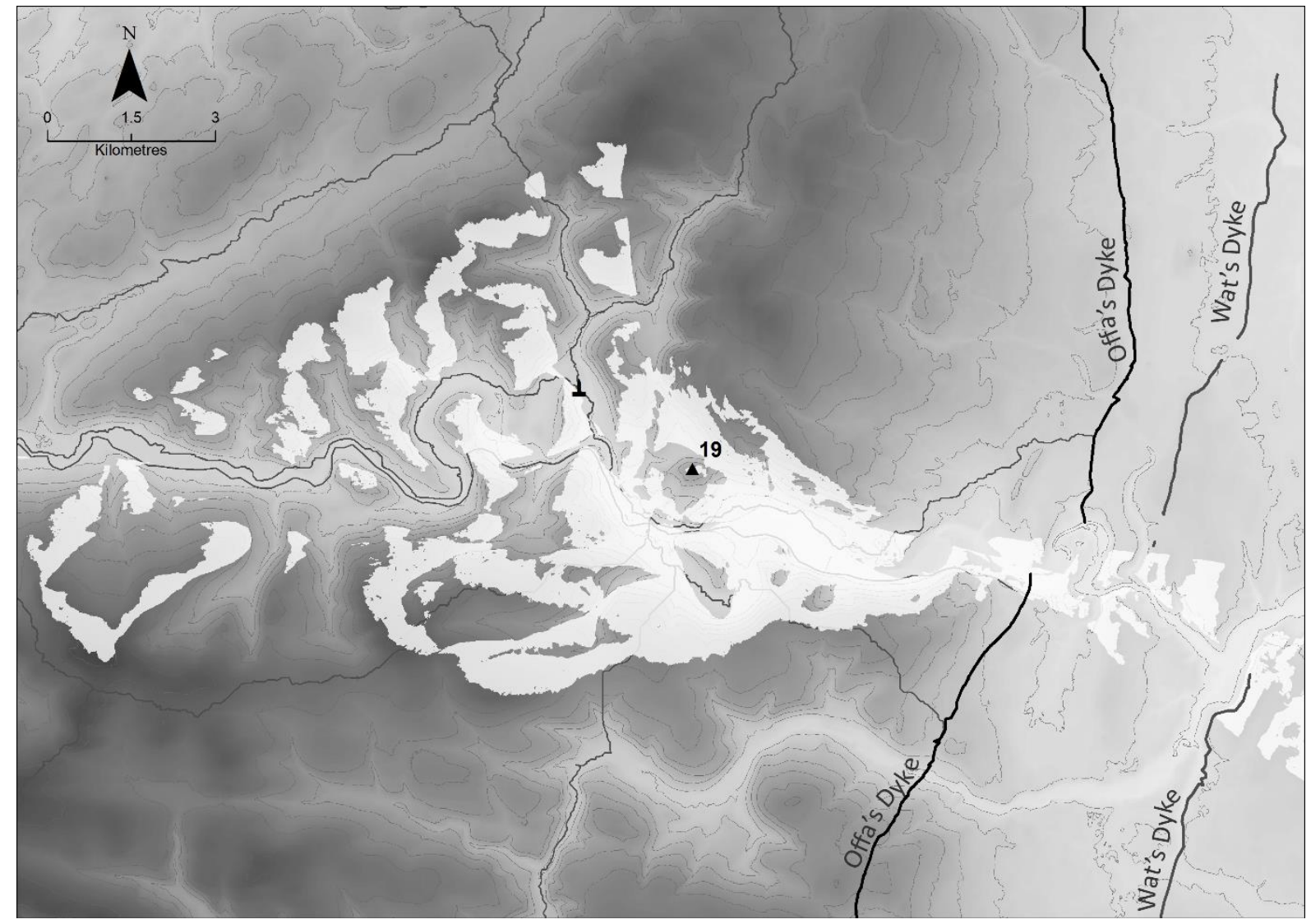

FIG 12

Viewshed from Castell Dinas Brân (location 19). Drawing by Patricia Murrieta-Flores. Base map Crown Copyright and Database Right [2012]. An Ordnance Survey Edina supplied service. 


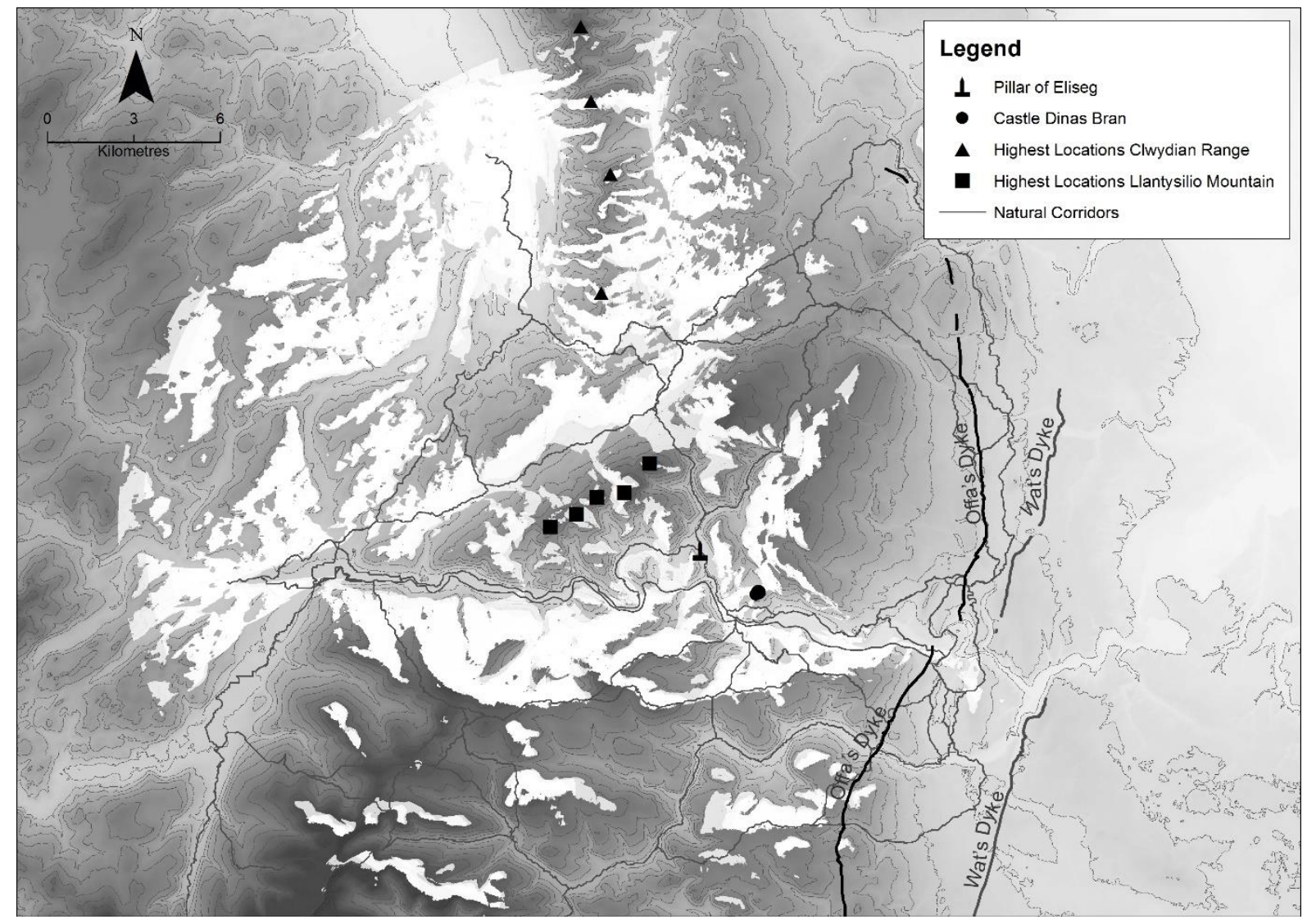

FIG 13

Viewshed from the highest locations at the Llantysilio Mountain. Drawing by Patricia Murrieta-Flores. Base map Crown Copyright and Database Right [2012]. An Ordnance Survey Edina supplied service. 


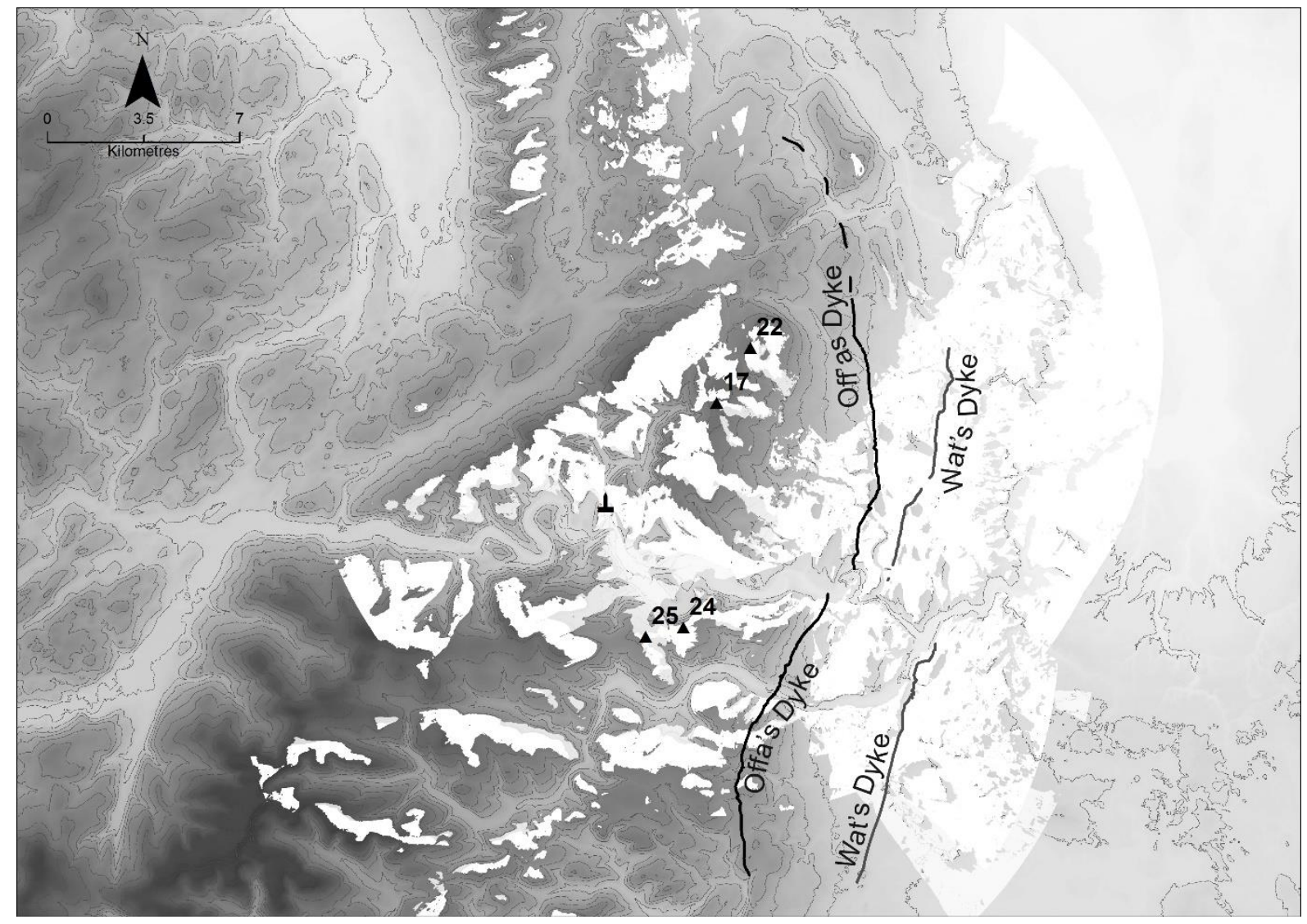

FIG 14

Only four locations are necessary to visually control up to $63 \%$ of Offa's dyke. Drawing by Patricia Murrieta-Flores. Base map Crown Copyright and Database Right [2012]. An Ordnance Survey Edina supplied service. 


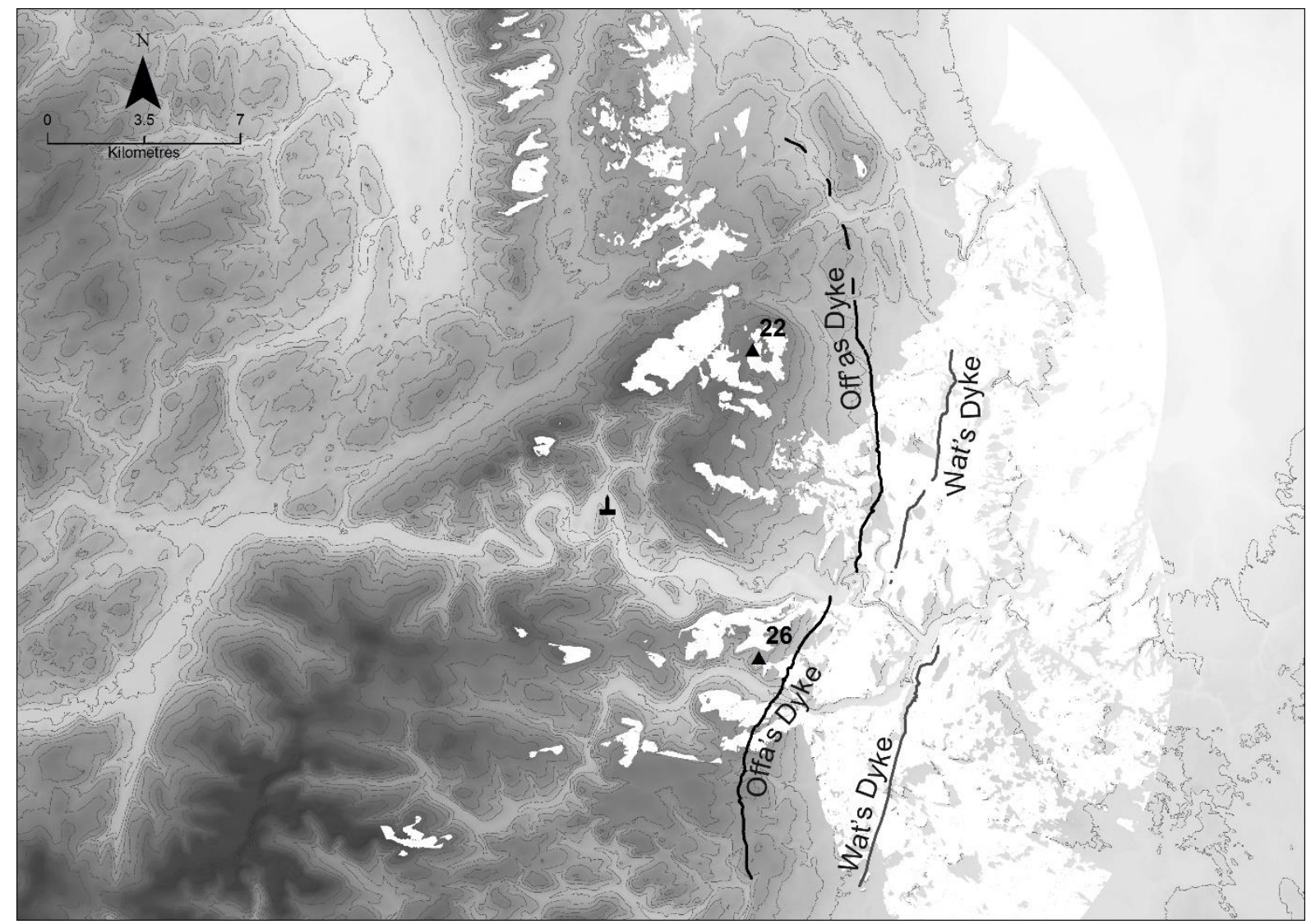

FIG 15

The two hypothetical locations necessary to visually control movement along $92 \%$ of the known route of Wat's Dyke. Drawing by Patricia Murrieta-Flores. Base map Crown Copyright and Database Right [2012]. An Ordnance Survey Edina supplied service. 


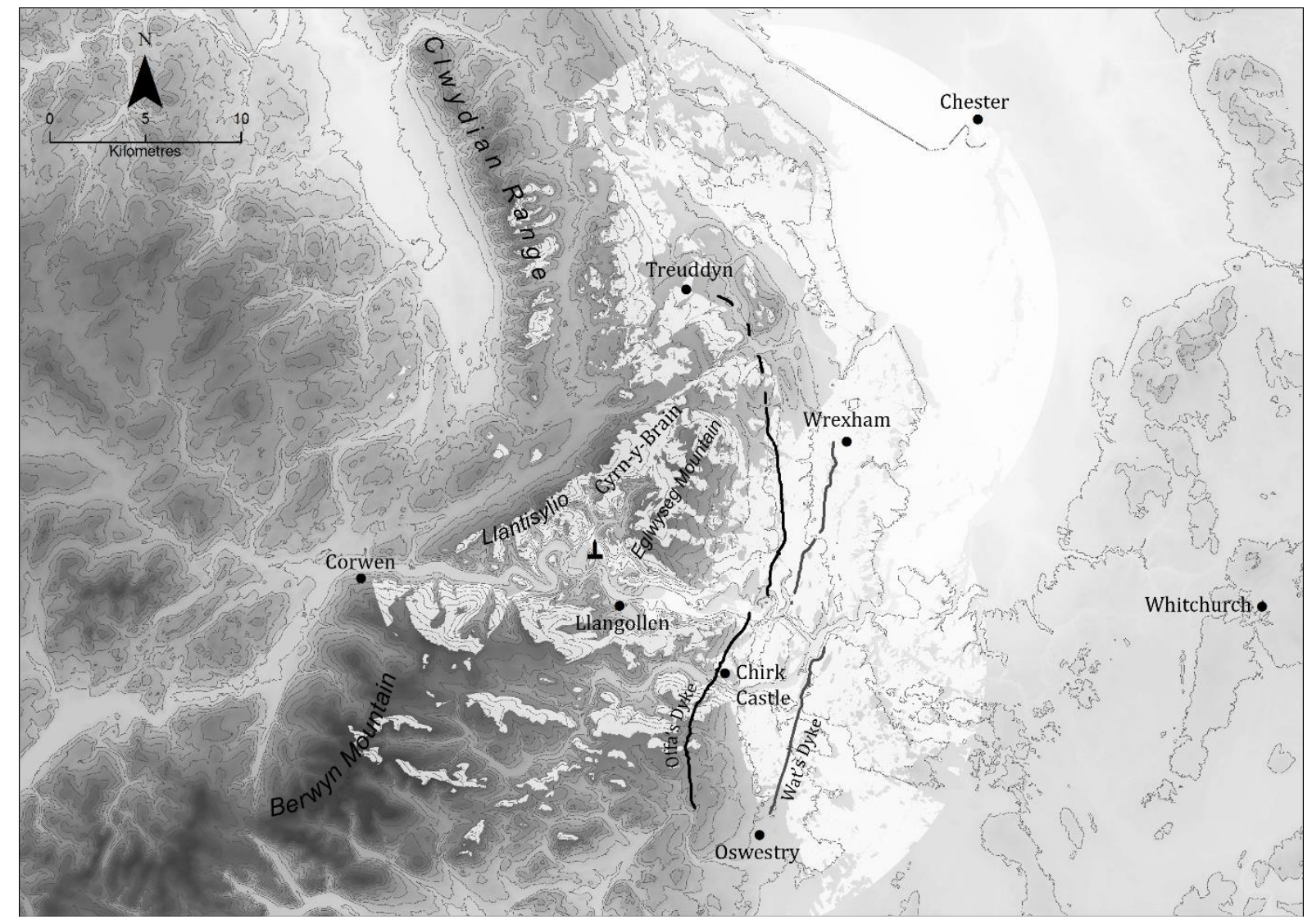

FIG 16

Visibility from Offa's Dyke's surviving stretches. Drawing by Patricia Murrieta-Flores. Base map Crown Copyright and Database Right 2012. An Ordnance Survey Edina supplied service. 


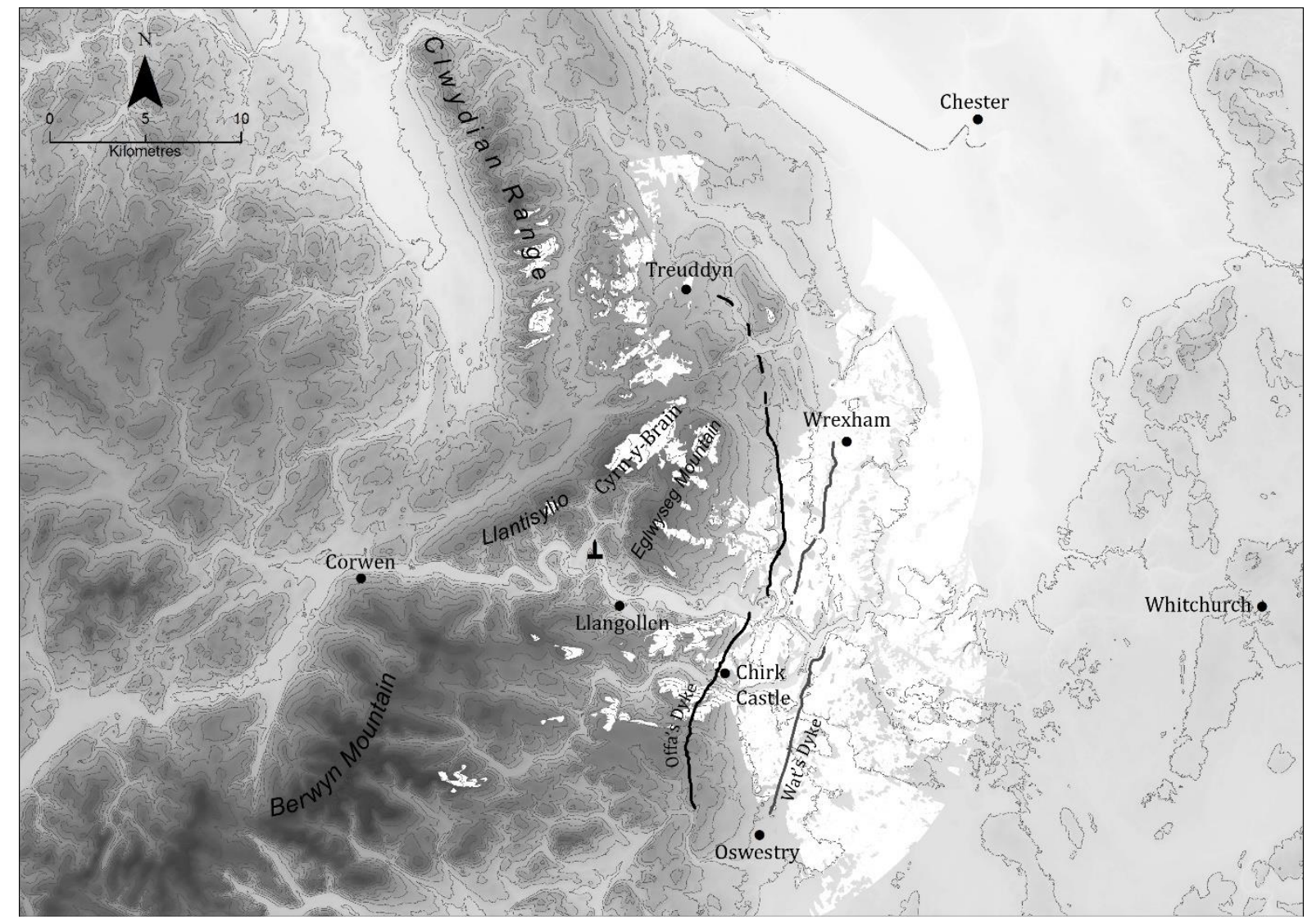

FIG 17

Visibility from Wat's Dyke's surviving stretches. Drawing by Patricia Murrieta-Flores. Base map Crown Copyright and Database Right [2012]. An Ordnance Survey Edina supplied service. 
${ }^{1}$ Dr Patricia Murrieta-Flores, Digital Humanities Research Centre, University of Chester.

p.murrietaflores@chester.ac.uk

2 Prof Howard Williams, Department of History and Archaeology, University of Chester. howard.williams@chester.ac.uk

${ }^{3}$ Williams et al 2015a.

${ }^{4}$ Back Danielsson 2015; Coatsworth 2015; Crouwers 2015; Edwards 2001; Hall 2015; Reynolds and Langlands 2011; Williams 2011; Williams et al 2015 b

${ }^{5}$ Edwards 2001; 2008; 2009; 2013a, 322-36; 2013b, 56-8.

${ }^{6}$ Edwards 2009, 146-9; 2013 a, 322-36.

${ }^{7}$ Charles-Edwards 2013, 417; Edwards 2009, 155-68; 2013a, 322-36; Williams 2011, 17-20.

${ }^{8}$ Edwards 2009, 170.

${ }^{9}$ Edwards et al 2011; 2013; 2014; < https://projecteliseg.wordpress.com/ > 09-01-17

${ }^{10}$ Edwards 2001; 2009; 2013a and b; Williams 2011.

11 Williams 2006; 2011.

12 Davies 1982, 104-6.

${ }^{13}$ Edwards 2009, 143-9; Edwards et al 2011; 2013a; 2014.

${ }^{14}$ Eg Hall 2015.

${ }^{15}$ Edwards et al forthcoming.

${ }^{16}$ Tong et al 2015.

${ }^{17}$ Eg Brookes 2007; Williams et al 2010; see now Baker and Brookes 2015a; Semple and Sanmark 2013.

18 Baker and Brookes 2015a, 9; Bradley 1987; Darvill 2004; Semple 2013; Semple and Sanmark 2013, 532-4b; Williams 2006.

${ }^{19}$ Williams 2011, 24-5.

${ }^{20}$ Edwards et al forthcoming.

${ }^{21}$ Edwards 2009, 163; Williams 2011.

22 Edwards 2013, 377-85.

23 Bennett 1995; Pratt 1995; Sherratt 2000; Silvester and Hankinson 2002; Clwyd-Powys Archaeological Trust 2015a.

${ }^{24}$ Williams 1990, 105.

${ }^{25}$ Cf Semple and Sanmark 2013, 528-32; parallels might be found in the work of Elizabeth Fitzpatrick on the relationship between assembly places, ancient monuments and landscapes of varied geologies making them attractive for seasonal hunting: Fitzpatrick 2012; 2015.

${ }^{26}$ Edwards 2009, 149; Williams 2011, 24.

${ }^{27}$ Cf. Seaman 2016.

28 Ibid, 41; see also Kightly 2003; Edwards 2008; Clwyd-Powys Archaeological Trust 2015b.

${ }^{29}$ Silvester and Evans 2009; cf Davies 1982, 140-3; Charles-Edwards 2013, 602-14.

${ }^{30}$ Edwards 2009, 168-9.

${ }^{31}$ Charles-Edwards 2004; Comeau 2014.

32 Edwards 2009, 152-5.

${ }^{33}$ Williams 2011, 24-5; cf Kirton 2015.

${ }^{34}$ Edwards 2013, 324-5.

35 Williams 2011; see also Kirton 2015; Williams et al 2015b; Williams 2016.

${ }^{36}$ For a view of assembly places as zones in the early medieval Welsh landscape, see Comeau 2014, $278-81$. See Seaman $(2016,41)$ regarding the twinning of ecclesiastical and hill-top sites which might provide parallels to the association of the Pillar with Castell Dinas Brân and Llangollen.

37 cf Back Danielsson 2015.

${ }^{38}$ Fox 1955; Noble 1983; ; Hill and Worthington 2003; Ray and Bapty 2016.

${ }^{39}$ Hayes and Malim 2008, 172-8, see also Worthington 1997; Worthington Hill and Greig 2015, 162-6, 176-7. Although, note reservations regarding the dating by Ray and Bapty 2016, 20.

40 Lock 2000; Earl et al 2013; Frachetti 2006; 2008; Lake and Woodman 2003; Llobera 2007a, 2007b; Llobera and Sluckin 2007; Mlekuž 2010; 2014; Murrieta-Flores 2012; 2013; 2014; Verhagen 2010; Wheatley et al 2010; Wheatley and Gillings 2002.

${ }^{41}$ Baker and Brookes b, 228; Brookes 2013, 43-4; Hill and Worthington 2003, 98-9, 126-8.

42 Tabik et al 2015.

${ }^{43}$ Murrieta-Flores 2012; 2013; Tabik et al 2015.

${ }^{44}$ Schneider and Robbins 2009. 
${ }^{45}$ Edwards 1987, 352-61

${ }^{46}$ Baker and Brookes 2015b; Brookes 2013; Hindle 2015; Malim 2007; Reynolds and Langlands 2011.

${ }^{47}$ Herzog 2010, 433.

${ }^{48}$ Murrieta-Flores 2012, 131.

${ }^{49}$ Wheatley and Gillings 2002, 181.

${ }^{50}$ Gillings and Wheatley 2001; Frieman and Gillings, 2007; Llobera, 2007a, 2007b; Wheatley, 2014.

${ }^{51}$ Kirton 2015; Reynolds and Langlands 2011, 421-2.

${ }^{52}$ Conolly and Lake 2006, 225-33; Wheatley and Gillings 2002, 205.

${ }^{53}$ Wheatley 1995; Wheatley and Gillings 2002, 202-16.

${ }^{54}$ Stewart 1998; Tabik et al 2011; Lindsay 2014; Tabik et al 2015.

55 Llobera 2007a;2007b; Guth 2009.

${ }^{56}$ Clwyd-Powys Archaeological Trust 2015b.

${ }^{57}$ Hankinson 2002; Silvester and Hankinson 2002.

${ }^{58}$ Charles-Edwards 2013, 414-24; Hill 2000, 202-3; Worthington 1997; Ray and Bapty 2016, 270-72.

${ }^{59}$ Hayes and Malim 2008, 173.

${ }^{60}$ Worthington 1997; Swallow 2016.

${ }^{61}$ Williams and Murrieta-Flores forthcoming.

${ }^{62} \mathrm{Cf}$ Reynolds and Langlands 2011.

63 Ibid 419-23.

${ }^{64}$ Clwyd-Powys Archaeological Trust 2015b.

${ }^{65}$ Baker and Brookes 2015b.

${ }^{66} \mathrm{Hill}$ and Worthington 2003, 99.

${ }^{67}$ Simpson 1853, 57, 66, 74.

${ }^{68}$ Cf. Ray and Bapty 2016, 122-63

${ }^{69}$ Brookes 2013, 44; Ray and Bapty 2016, 156-63, 228-51; 350-64.

${ }^{70}$ Ray and Bapty 2016, 194-98; 275-83.

${ }^{71}$ While admitting the challenges of confirming the locations of gateways through Offa's Dyke, Ray and Bapty $(2016,228-51)$ propose convincing potential instances.

72 Malim 2007; Ray and Bapty 2016, Williams and Murrieta-Flores forthcoming.

${ }^{73}$ Brookes 2013, 44.

${ }^{74}$ Hill and Worthington 2003, although now also see Ray and Bapty 2016, 244-50.

${ }^{75}$ Insley 2012, 127.

${ }^{76}$ Noble 1983; see also Hill 2000, 182; Ray and Bapty 2016, 78.

${ }^{77}$ Edwards et al forthcoming.

${ }^{78}$ Edwards 2013a, 104.

$79 \mathrm{lbid}, 104,328$.

${ }^{80}$ Baker and Brookes 2015b,

${ }^{81}$ Charles-Edwards 2013, 422; Gelling 1992, 113-14; Hill and Worthington 2003, 46, 173-80; Molyneaux 2011, 249; Ray and Bapty 2016, 266-67.

${ }^{82}$ Gelling 1992, 112-18; Molyneaux 2011, 251.

${ }^{83} \mathrm{lbid}, 269$.

${ }^{84}$ Besly 2006, 702; Redknap 2007; Molineaux 2011, 2072.

${ }^{85}$ Ray and Bapty 2016, 344-46

${ }^{86}$ Charles-Edwards 2013, 426.

${ }^{87}$ Ray and Bapty 2016, 254-97;

${ }^{88}$ Edwards 2013a, 114.

${ }^{89}$ Ingram 1912a, 822, 828; Kirby 2002, 154.

${ }^{90}$ Bailey 2010, 34; Edwards 2013a, 329.

${ }^{91}$ Charles-Edwards 2013, 418-19.

${ }^{92}$ Edwards et al forthcoming.

${ }^{93}$ Baker and Brookes 2015b.

${ }^{94}$ Edwards 2009, 168-9.

${ }^{95}$ Baker 2011; Baker and Brookes 2015a, 12-18; Baker and Brookes 2015b for the reuse of hillforts as lookout points in Anglo-Saxon England.

${ }^{96}$ Hill 2001, 177.

${ }^{97}$ Cf Malim 2007, 27-32. 